\title{
Transferosomes as nanocarriers for drugs across the skin: quality by design from lab to industrial scale
}

\section{Raquel Fernández-García ${ }^{1}$, Aikaterini Lalatsa ${ }^{2}$, Larry Statts ${ }^{2}$, Francisco Bolás-Fernández ${ }^{3}$, M. Paloma Ballesteros ${ }^{1,4}$, Dolores R. Serrano ${ }^{1,4^{*}}$}

\footnotetext{
${ }^{1}$ Departamento de Farmacia Galénica y Tecnología Alimentaria, Facultad de Farmacia, Universidad Complutense de Madrid. Plaza Ramón y Cajal, s/n, 28040, Madrid (Spain).

${ }^{2}$ School of Pharmacy and Biomedical Sciences, University of Portsmouth, St. Michael's Building, White Swan Road, Portsmouth, PO1 2DT (U.K.).

${ }^{3}$ Departamento de Microbiología y Parasitología, Facultad de Farmacia, Universidad Complutense de Madrid. Plaza Ramón y Cajal, s/n, 28040, Madrid (Spain)

${ }^{4}$ Instituto Universitario de Farmacia Industrial, Facultad de Farmacia, Universidad Complutense de Madrid (Spain)
}

*Corresponding author

Dolores R. Serrano

Departmento de Farmacia Galénica y Tecnología Alimentaria

Facultad de Farmacia

Universidad Complutense de Madrid

Email: drserran@ucm.es

Tel: +34913941620 


\section{Abstract}

Transferosomes, also known as transfersomes, are ultradeformable vesicles for transdermal applications consisting of a lipid bilayer with phospholipids and an edge activator and an ethanol/aqueous core. Depending on the lipophilicity of the active substance, it can be encapsulated within the core or amongst the lipid bilayer. Compared to liposomes, transferosomes are able to reach intact deeper regions of the skin after topical administration delivering higher concentrations of active substances making them a successful drug delivery carrier for transdermal applications. Most transferosomes contain phosphatidylcholine $(\mathrm{C} 18)$ as it is the most abundant lipid component of the cell membrane, and hence, it is highly tolerated for the skin, decreasing the risk of undesirable effects, such as hypersensitive reactions. The most common edge activators are surfactants such as sodium deoxycholate, Tween ${ }^{\circledR} 80$ and Span ${ }^{\circledR} 80$. Their chain length is optimal for intercalation within the $\mathrm{C} 18$ phospholipid bilayer. A wide variety of drugs has been successfully encapsulated within transferosomes such as phytocompounds like sinomenine or apigenin for rheumatoid arthritis and leukaemia respectively, small hydrophobic drugs but also macromolecules like insulin. The main factors to develop optimal transferosomal formulations (with high drug loading and nanometric size) are the optimal ratio between the main components as well as the critical process parameters for their manufacture. Application of quality by design (QbD), specifically design of experiments (DoE), is crucial to understand the interplay among all these factors not only during the preparation at lab scale but also in the scale-up process. Clinical trials of a licensed topical ketoprofen transferosomal gel have shown promising results in the alleviation of symptons in orthreothritis with non-severe skin and subcutaneous tissue disorders. However, the product was withdrawn from the market which probably was related to the higher cost of the medicine linked to the expensive manufacturing process required in the production of transferosomes compared to other conventional gel formulations. This example brings out the need for a careful formulation design to exploit the best properties of this drug delivery system as well as the development of manufacturing processes easily scalable at industrial level.

Key words: transferosomes, ultradeformable vesicles, transdermal administration, natural products, edge activator, quality by design $(\mathrm{QbD})$ 


\section{Skin as a barrier for topical and transdermal therapies}

Skin is the largest interface between the human body and the external environment (Prausnitz et al., 2012). Being the body's largest organ (Hadgraft and Lane, 2011), skin maintains body's homeostasis by regulating the entrance and clearance of different substances, preventing excessive water loss and maintaining body temperature. However, exchange of substances across the skin is very limited as its primary function is protection compared to the gastrointestinal tract or the lung epithelial which are designed for compound exchange (Prausnitz et al., 2012).

Skin is composed of three main layers: the epidermis (the outer layer), the dermis (the middle layer containing sensory receptors, sweat glands and various connective fibers) and the hypodermis (subcutaneous layer which contains adipose tissue and anchors the other two outer layers of the skin for support) (Hadgraft and Lane, 2011). The outermost layer of the skin, the "stratum corneum" (SC) which is made up of a broad 10-15 $\mu \mathrm{m}$ size matrix of flattened, dehydrated and dead keratolytic cells (corneocytes), that are surrounded by an extracellular milieu of lipids organized as multiple lamellar bilayers, remains the main barrier to the topical or transdermal delivery (Rane and Gujarathi, 2016). The structure of the SC is a composite material made of proteins and lipids structurally organized as "bricks and mortar" (Prausnitz et al., 2012; Rane and Gujarathi, 2016) in which the corneocytes are envisaged as the bricks and the intercellular lipids and esters organized into lamellar membranes surrounding the corneocytes being the mortar that holds them together (Kleesz et al., 2012). The human SC is typically comprised of about 20 corneocyte cell layers with varying thickness, packing of keratin filaments, filaggrin content and a number of corneodesmosomes depending on the site. A highly cross-linked sheath surrounds corneocytes, while their cell interior is packed with keratin filaments embedded in a filaggrin matrix. The extracellular matrix comprises of structured lipids preventing excessive loss of water from the body and block the entry of most topically applied drugs, except those that are lipophilic (Log P: 1-3) and with low molecular weight $(<500 \mathrm{Da})$ for which this extracellular, lipid-enriched matrix acts as a reservoir within which lipophilic drugs can accumulate and be slowly released (Prausnitz et al., 2012). Although corneocytes play a role as spacers and as a scaffold for the lipidenriched extracellular matrix, the latter has been the primary focus of transdermal delivery strategies. 
Nanoparticulate delivery systems offer advantages in overcoming the SC as they have shown to enable the delivery and permeation of hydrophilic compounds and biomacromolecules to reach deeper layers of the skin, provide a sustained depot effect locally and increase transdermal delivery resulting in enhanced bioavailability. In particular, transferosomes are advantageous over other nanoparticulate drug delivery systems in the administration of drugs across the skin as their composition contains a greater amount of safe and biocompatible excipients (phospholipids, commonly soya lecithin) and have the capability of squeezing and permeate across the SC and deeper layers of the skin without losing their structure (Rajan et al., 2011). The differentiating effect will be discussed over the next sections.

\section{Transferosomes}

\subsection{Transferosomes: versatile and flexible nano-vesicular carriers}

The word transferosome is a registered trademark by the German company IDEA AG and the name derives from the Latin word "transferre" meaning "to carry across" and the Greek word "soma" meaning "body". The technology was first described in 1991 by Çevc and Blume and has been the subject of several patents and research over the last 30 years (Naik, 2013; Rai et al., 2017). Although there has been almost 30 years since the first time that the term transferosome has been used, this drug delivery system can still be considered novel as very few transferosomal formulations have been translated into clinical products. Similar trend has occurred with liposomes. The first report about liposomes in literature dates from 1970 (Sessa and Weissmann, 1970), being AmBisome ${ }^{\circledR}$, one of the first liposomal formulations coming to the market in 1996 (AEMPS, 2017). For this reason, it can be expected that more transferosomes will be commercialized in the following coming years.

Transferosomes are lipid-based vesicular carriers that compared to the rigid lipid bilayers (liposomes) or non-ionic surfactant single layer vesicles (niosomes) are elastic, ultradeformable and stress-responsive (Rajan et al., 2011). When drug delivery systems, such as liposomes, nanoparticles and niosomes are deposited on the skin, usually they are only able to permeate through the upper layers of the SC, resulting in accumulation in the epidermal layer but failing to reach deeper areas of the skin such as the dermis or effective systemic levels. Liposomes are by far one of the most commonly used drug delivery system for skin purposes. However, the mechanism of liposomal permeation is still not 
fully understood. Several authors support that small unilamellar liposomes have greater skin permeation capacity than larger ones (Verma et al., 2003). For example, liposomes with a $120 \mathrm{~nm}$ particle size reached to deeper skin areas (viable epidermis and dermis) in 4.6-fold greater amounts than liposomes with $191 \mathrm{~nm}$ in size and 33-fold higher than 810 nm liposomes (Verma et al., 2003). In addition, multilayered liposomes have been shown to be able to loose external layers during penetration facilitating the permeation of smaller vesicles with intermediate size $(100-300 \mathrm{~nm}$ ) leading to deeper drug penetration (Morrow et al., 2007). Hyaluronate chitosan multilayer liposomes (containing 10 alternating layers) with $528 \mathrm{~nm}$ particle size exhibited an enhanced transdermal delivery than uncoated unilamellar liposomes ( $100 \mathrm{~nm})$ (Jeon et al., 2015). Similarly, multilayered nanostructured lipid nanoparticles coated with hyaluronic acid and chitosan (181 nm) showed a two-fold larger flux across rat skin compared to uncoated nanoparticles (Zhang et al., 2016). In contrast, other authors support that multilamellar and small unilamellar liposomes possess similar ability to penetrate into the SC and viable skin (Lymberopoulos, 2017). Liposomes penetrate mainly into the SC but as much lesser extent in the epidermis and dermis (800 and 10,000 times less) (Lasch, 1992). Actually, more than size, their lipid composition plays a greater role in the skin permeation. Liposomal lipids can penetrate until $20 \mu \mathrm{m}$ reaching the viable epidermis in greater amount than the whole liposomes per se (Peralta et al., 2018). Only liposomes containing dioleoylphophatidylethanolamine (DOPE) as lipid were able to penetrate into deeper stratum corneum (Lasch, 1992). Regarding niosomes, their penetration capacity has been associated with reduced fluxes across the SC compared to conventional liposomes even though are more stable and resistant to changes in osmolarity (Agarwal et al., 2001; Naik, 2013; Rai et al., 2017; Rajan et al., 2011). In terms of zeta-potential, transferosomes seem have shown the greatest colloidal stability when compared to liposomes and niosomes in liquid media (van Zyl et al., 2019); transferosomes have exhibited good colloidal stability (with no sign of aggregation) up to three months both at $4{ }^{\circ} \mathrm{C}$ and $25{ }^{\circ} \mathrm{C}$ (Hadidi et al., 2018), while niosomes and liposomes have shown poorer physical stability with greater tendency for aggregation at the same temperatures (Fathi-Azarbayjani et al., 2015). This fact can explain why most of the commercial liposomal formulations are marketed as freeze-dried powders in order to enhance the shelf-life of the product (AEMPS, 2017).

Transferosomes are composed by four key elements: i) phospholipids (such as phosphatidylcholine, dipalmitylphosphatidylcholine, distearylphosphatidylcholine), ii) 
an edge activator such as a surfactant or bile salt ranging from 10-25\% (e.g. sodium cholate, sodium deoxycholate, Tween ${ }^{\circledR} 80, \operatorname{Span}^{\circledR} 80$, dipotassium glycyrrhizinate), iii) ethanol in a lower percentage usually below $10 \%$ (as higher concentrations are described as ethosomes) and iv) water as a vehicle (Fig. 1) (Rai et al, 2017; Rajan et al, 2011; Morrow et al, 2007). Transferosomes are highly ultra-deformable and are able to squeeze through the SC and penetrate as intact vesicles through the skin when their size is below $300 \mathrm{~nm}$ and when they are applied under non-occlusive conditions that maintains the trans-epidermal osmotic gradient which acts as the driving force for the elastic transport into the skin (Naik, 2013; Rai et al., 2017; Rane and Gujarathi, 2016).

In this respect, the edge activator plays a key role as it provides a high radius of curvature that can destabilize the lipid bilayer increasing the deformability of the membrane. This allows transferosomes to spontaneously squeeze though channels in the SC that are less than one-tenth the diameter of the vesicles and prevents vesicle rupture when crossing through the different skin layers (Naik, 2013; Rane and Gujarathi, 2016). The concentration of the edge activator in the formulation (usually between 10-20\%) is crucial and ideally included in sub-lytic concentrations i.e. not able to cause destruction of vesicles (Naik, 2013; Rai et al., 2017; Rajan et al., 2011). The risk of formation of mixed micelles increases when amounts of edge activator greater than $15 \%$ are used (Jangdey et al., 2017).

Hydrophilic drugs are encapsulated within the aqueous central cavity, while more hydrophobic drugs are embedded within the phospholipid bilayer. Transferosomes are typically below $300 \mathrm{~nm}$ being more elastic and flexible than liposomes (typically fiveeight times higher), which makes them highly suitable for skin penetration (Rai et al., 2017; Rane and Gujarathi, 2016), although higher sizes can be obtained due to the aggregation of the particles. An optimal zeta-potential in transferosomes is lower than $30 \mathrm{mV}$ or higher than $+30 \mathrm{mV}$ in order to ensure colloidal stability; otherwise the risk of aggregation increases significantly (Hanaor et al., 2012).

\subsection{Mechanism of transferosome penetration across the SC}

As these novel artificial carriers are self-adaptable, they can go through pores much smaller than their own size by changing their shape and size easily and rapidly, by adjusting lipid bilayer components to the surrounding stress experienced by the system, and thus being able to carry drugs with a high molecular weight across the intact skin 
(Fig. 2). As these molecules with a high molecular weight are barely able to reach the deepest layers of the skin and the bloodstream, transferosomes are an alternative to subcutaneous administration of insulin or IFN- $\alpha$, showing a $50 \%$ of response when compared with insulin and sufficient concentration of IFN- $\alpha$ for immunotherapy (Reddy, 2015). When transferosomes are administered on the surface of the skin, they are able to permeate across the different layers of the skin by going through the intercellular lipids as well as lipid cell membranes (Rai et al., 2017; Rane and Gujarathi, 2016). The skin penetration of these vesicles lies on the interdependency of the local composition and shape of the bilayer which makes the vesicle both self-regulating and self-optimizing enabling the transferosomes to cross various transport barriers efficiently and then acting as a drug carrier for non-invasive targeted drug delivery and sustained release of therapeutic agents (Rai et al., 2017; Rajan et al., 2011; Rane and Gujarathi, 2016).

The penetration of intact transferosomes through the SC occurs due to the "transdermal osmotic gradient" caused by the difference in water content between the relatively dehydrated skin surface (approximately $15 \%$ water) and the aqueous viable epidermis (close to $75 \%$ ) (Rajan et al., 2011). This difference in hydration is a physiological feature of the skin in order to prevent water loss. Based on the principles of elastomechanics, the hydrophilic lipid vesicles establish an energetically favorable interaction, which force them to escape from the complete drying environment moving them to more hydrated regions (Naik, 2013; Rai et al., 2017; Rajan et al., 2011). Hence, transferosomes are subject to evaporation and in order to avoid dehydration, the vesicles deform, penetrate across the SC, and travel towards deeper and more aqueous areas of the skin to rehydrate (Rai et al., 2017). Transferosomes have the ability to modify their shape, but the internal entrapped volume capacity does not change drastically and therefore the solubility of the entrapped drug in the core should not be altered significantly. Small breakages could occur in the lipid bilayer due to the deformation during the penetration across the skin resulting in the partial release of ethanol/water content from the core. However, this situation is reverted during the rehydration process with water from the viable epidermis.

The flexibility of the transferosomal membrane decreases the risk of complete vesicle rupture in the skin and allows the transferosomes to change their membrane composition locally and reversibly, while passing through the intercellular gaps and intracellular lipid cell membranes. This self-optimizing deformability allows the transferosomes to dehydrate and deform to cross through small gaps while they can recover their shape by 
a rehydration process (Naik, 2013; Rai et al., 2017; Rajan et al., 2011). Actually, these rheological and hydration properties responsible for their great deformability are attributed to the combination of the phospholipids and edge activator in an optimal ratio (Rajan et al., 2011).

Previous research suggested that the penetration of the formulation through the skin is forced by a osmotic gradient that is caused by the different water content between the relatively dehydrated skin surface (with $\mathrm{a} \approx 20 \%$ of water) and the aqueous viable epidermis ( $\approx 75 \%$ water content). A lipid formulation applied in the surface of the skin avoids evaporation and, consecuently, dehydration, allowing transferosomes to reach deeper layers of the skin (Benson, 2006). In the case of PEGylated transferosomes containing terpenes as edge activators, apart from the good elastic characteristics of the transferosomes, a greater in vitro/in vivo performance has been associated with the fact that terpenes-containing vesicle bilayers could enter the SC by altering the intercellular lipids lamellar and also by the effect of PEG that could hydrate the skin facilitating the transport based on the hydration gradient (Wang et al., 2017).

A sustained drug release can occur from transferosomal formulations. It has been reported a burst effect from transferosomes during the first 4 hours upon administration followed by a slow release afterwards. Considering that hydrophilic drugs are located in the core of the transferosome, their release would be slower compared to hydrophobic drugs, which are located in the lipid bilayer. However, the burst effect observed during the first hours upon administration has been also linked with a small breakage of the lipid bilayer due to the vesicle deformation taking place during the permeation, allowing a partial release of the drug located in the core (Omar et al., 2019). PEG-coating in the surface of the transferosome has also lead to sustained drug release during prolonged periods of time (Panwar et al., 2010).

\section{Transferosomes in preclinical studies - Laboratory scale preparation}

The thin film hydration technique is the most widely strategy to prepare transferosomes at lab-scale (Table 1). The main advantages of this technique when a suitable ratio between lipid:edge activator:drug is selected are that nanometric particle size, high entrapment efficiency and high yield can be easily obtained. The thin film hydration technique is the most common method at lab scale, due to the simplicity of the technique and the short time required to prepare the formulation. However, this technique has 
several limitations including poor scalability mainly related to the fact that the particle size of the formulation is highly dependent on the volume capacity of the equipment employed and the energy applied in the process (Kraft et al., 2014). The desired features of the transferosomes can be easily altered during the scaling-up of this method (Paliwal et al., 2014). For example, it was proven that the particle size was reduced when greater impeller speed and agitation times were used (Colombo et al., 2001). In addition, this bottom-up approach is less popular in industry as it requires removal of the traces of the remaining solvent (Junghanns and Muller, 2008). Other disadvantage associated with this technique is that often requires a downsizing technique to make the transferosomes more uniform and within the nanometric range (Wagner and Vorauer-Uhl, 2011). The scale-up of this downsizing step is challenging at industrial level.

Most transferosomes contain phosphatidylcholine (C18) as the lipid fraction (usually above $70 \%$ ) as it is the most abundant lipid component of the cell membrane, and hence, it is highly tolerated for the skin, decreasing the risk of undesirable effects, such as hypersensitivity reactions (Ishikawa et al., 2017). Soya phosphatidylcholine (>95\% purity) is a GRAS (Generally Regarded As Safe) excipient and actually it has been used in suspensions, emulsions, mixed micelles, solid dispersions and drug-phospholipid complexes with a good safety profile (Rajan et al., 2011; van Hoogevest and Wendel, 2014).

The most common edge activators employed are sodium deoxycholate, Tween ${ }^{\circledR} 80$ (polyoxyethylene 20 sorbitan monooleate) and Span® 80 (sorbitan monooleate) as their chain length is easier to intercalate within the C18 phospholipid bilayer (El Maghraby et al., 2004). There is a certain discrepancy amongst the results collected from the different studies included in Table 1. For this reason, a multilinear regression analysis was performed in order to evaluate the correlation between the percentage of lipids and edge activator in each formulation and the particle size, zeta-potential and permeability (Fig. 3). Formulations containing an ionic edge activator, such as sodium deoxycholate, were analysed separated from those formulated with non ionic surfactant such as Tween ${ }^{\circledR} 80$ or $\operatorname{Span}^{\circledR}$ 80. Overall, the general trend indicated that higher percentage of sodium deoxycholate led to lower particle size while large amounts of non ionic surfactants resulted in an increase in particle size. This is probably related with the volume of the polar head of the non ionic surfactants and with the greater intercalation of the sodium deoxycholate within the lipid bilayer leading to an increase in the curvature of the 
transferosomes. Regarding the in vitro permeability, there was a positive correlation between the amount of sodium deoxycholate and the permeability across the skin. Opposite effect was observed for those transferosomes containing non ionic edge activators which can be related to the larger particle size obtained with larger amounts of this type of surfactant.

The percentage of edge activator ranges from $4 \%$ till $20 \%$ (Table 1). Overall, drug entrapment is improved when higher concentrations of edge activator are employed (usually up to $10 \%$ ). However, a ratio above $10 \%$, in the case of valsartan transferosomes, led to lower drug encapsulation (from 93.56 to $62.73 \%$ ) because the lipid bilayer of the transferosome becomes disrupted and more leaky releasing the entrapped drug (Ahad et al., 2012b). Also mixed micelles can co-exist with transferosomes when the surfactant exceeds $15 \%$ of the total composition, resulting in partial drug encapsulation within small size micelles and hence, lower drug entrapment within the transferosomes (Jangdey et al., 2017). Larger entrapment values were obtained when $\operatorname{Span}^{\circledR} 80$ was used as edge activator (1.5-fold higher entrapment efficiency than using sodium deoxycholate), while transferosomes including sodium deoxycholate have resulted in better permeation across the SC (16.8 versus 9-fold greater permeability) (Ahad et al., 2017). Better in vitro skin permeation and in vivo PK cutaneous permeability in microdialysis studies than conventional liposomes has been reported when monoterpenes such as limonene and citrol have been incorporated as edge activators (Wang et al., 2017). Also, the combination of phosphatidylcholine with DSPE-PEG2000 has resulted in an increase in the transdermal permeation of the transferosomes (Wang et al., 2017).

Span ${ }^{\circledR} 80$ have been shown to act as a destabilizing agent and leads to highly deformable vesicles with enhanced permeation (Pathak et al., 2016). The hydrophilic-lipophilic balance (HLB) of the surfactant has an effect on particle size. The lower the HLB, the larger the particle size (Ahmed, 2015). The hydration medium temperature has also some influence in the final particle size. More stable smaller vesicles were obtained at temperatures around $20^{\circ} \mathrm{C}$ (Ahmed, 2015).

Drugs with different physicochemical characteristics have been successfully entrapped in transferosomes ranging from small molecular weight hydrophobic drugs and phytocompounds (such as sinomenine or apigenine for rheumatoid arthritis and 
leukaemia) to labile biomacromolecules such as insulin (>5 kDa) (Table 1). Drug loading can be tuned easily being able to encapsulate potent drugs at low doses such as tretinoin at $0.05 \%$ but also high drug loading up to $20-25 \%$ like in the case of sinomenine. However, drug loading above $20 \%$ is challenging considering the amounts of lipid and edge activator needed to produce stable transferosomes. Thus, entrapment of potent drugs is more likely to lead to clinically translatable formulations. 


\section{Optimising transferosomal formulations using quality by design (QbD)}

The concept of $\mathrm{QbD}$ is usually used in pharmaceutical development and manufacturing to enhance the quality of the obtained products (Adam et al., 2011). QbD is a systematic approach that starts with predefined objectives (also known as "Target Product Profile" or product specifications) and emphasizes on product critical quality attributes (CQAs), understanding of critical process parameters (CPPs) and process control (Fig. 4). This can be improved by building quality standards into the process of development and manufacturing and not only testing the product at the end of the process (Defeo, 2016; Rathore and Winkle, 2009).

This concept was introduced in the 2000s by the pharmaceutical industry combined with support from the Food and Drug Administration (FDA). Even though, the quality of the final products was usually ensured, a high percentage of the production was wasted because the quality control only took place at the end of the process, leading to higher costs associated with medicine manufacturing. Taking into account the high cost and complex production associated with nanomedicines, the optimisation of the manufacturing process is key to ensure that advance formulations, such as transferosomes, reach the market.

According to the $21^{\text {st }}$ Century Initiative, more controls were necessary to be implemented in manufacturing in order to improve efficiency and safety in the process leading to the establishment of GMP (Good Manufacturing Practices) (Rathore and Winkle, 2009). Since the FDA-GMP Initiative, new documents have been published by the International Conference on Harmonization (ICH) focused on the concept and implementation of QbD in pharma companies: Q8 Pharmaceutical Development, Q9 Quality Risk Management and Q10 Quality Systems Approach to Pharmaceutical GMP Regulations (Rathore and Winkle, 2009).

In pharmaceutical $R \& D$ (research and development), QbD, specifically design of experiments (DoE), is commonly used to obtain optimised formulations taking into consideration a wide range of factors that can affect the Target Product Profile, as experiments are set up in an efficient and precise way (Savic et al., 2012). Formulation optimisation usually takes place in several steps, starting with a pre-screening design (also known as ruggedness testing) (Chen et al., 2017; Zhao et al., 2017) in order to identify the critical main factors of the process (Yang et al., 2014) utilising the minimum number 
of experimental runs to be performed to ensure cost and time efficiency. Pre-screening is performed by using different types of factorial models, among which Plackett-Burman (Zhao et al., 2017) and Taguchi (Chen et al., 2017) are the most utilised. These models are useful to determine which factors have higher or lower, positive or negative influence in the development of the formulation (eg. amount of components or parameters in the manufacturing process). Once, the most influential factors have been identified with the pre-screening designs, response surface models are commonly employed to find the optimal design space. Mixture design spaces are also utilised where the suitable ratio between excipients needs to be identified but there is no investigation on the process parameters.

Plackett-Burman design can appraise between 2 to 47 factors, where each factor is set to 2 levels (higher and lower). This design can be applied to investigate up to $\mathrm{N}-1$ variables with $\mathrm{N}$ experiments (Zhao et al., 2017). This design is particularly useful to test ruggedness when the aim is focused on finding a small or non-existent effect due to the factors (Zhao et al., 2017). A ruggedness test determines the sensitivity of a protocol to small changes in operational factors (Parker et al., 2014). The Taguchi model is an orthogonal array design which evaluates two-level factorial designs (higher and lower) (Chen et al., 2017). This type of DoE reduces effectively the number of experiments required in a design process, instead of having to test all possible combinations: the model only tests pairs of combinations (Chen et al., 2017; Rao et al., 2008). Taguchi focuses on the concept of robust design methodology where variations due to noise factors beyond the control of the design are considered and the obtained responses are only affected by controllable factors (Rao et al., 2008).

Response surface methodology consists on a group of mathematical and statistical techniques based on the fit of empirical models to the experimental data obtained in relation to DoE (Bezerra et al., 2008). As an advance DoE technique designed to aid the better understanding and optimisation of the responses, it is often used to refine models once the major factors have been previously identified with a pre-screening test (Bezerra et al., 2008). There are two main types of response surface designs: the central composite and the Box-Behnken. A central composite design is a 2-full-factorial design that includes both the central and star points allowing estimation of curvature. The number of central points runs the design and the star points represent the extreme values (low and high) for each factor in the design. This design estimates efficiently first- and second-order terms 
and is especially useful in sequential experiments as previous factorial experimental data can be fed in the design. In contrast, Box-Behnken design requires fewer design points and hence is less expensive to run with the same number of factors, however, lacks the ability to incorporate data from previous experiments. Additionally, Box-Behnken design always have three levels per factor unlike central composites which can have up to five (Ferreira et al., 2007; Khajeh, 2009).

As a starting point in optimising transferosomal formulations, a mixture design can be applied taking into account that the suitable ratio among phospholipids, edge activator and drug should be identified utilising ternary diagrams (Fig 5A). The measured responses which are usually drug loading and particle size are assumed to depend only on the relative proportions of the excipients. Usually a fitting standard model is employed like Simplex-Lattice or Simplex-Centroid design, where the components must sum to one (or $100 \%$ ). However, they are usually combined with constrained mixture designs such as Extreme-Vertices design to introduce and define additional constrains such as the maximum and/or minimum value for each component. In the case of transferosomes, the amount of lipids needs to be always higher than the amount of edge activator to ensure formation of bilayered vesicles (Fig 5B-C) (Rispoli and Shah, 2008).

\section{Lab scale manufacture of QbD optimized transferosomes}

QbD has been employed in several studies towards preclinical development of transferosomal formulations (Table 2) (Csanyi, 2018; Gilani, 2019). The first example was the development of zolmitriptan transferosomes for migraine using phosphatidylcholine and Tween ${ }^{\circledR} 80$. The effect of the amount of phospholipid, drug and edge activator on particle size, drug release and flexibility index (parameter that determines the deformability capacity of the transferosome across membranes) was evaluated using a Box-Behnken design (Pitta et al., 2017). The flexibility index was determined by extruding the formulation through a $0.22 \mu \mathrm{m}$ filter assembled to a measuring cylinder and a vacuum pump. In order to determine the flexibility index, the particle size of the formulation was measured before and after passing through the filter for $15 \mathrm{~min}$. In this case, a mixture design would have been more suitable as no process variables were investigated. Transferosomes were prepared using the rotary film evaporation method. Optimized transferosomes with a particle size below $100 \mathrm{~nm}$, a flexibility index of $20.25 \%$ and a drug release of $97 \%$ after $10 \mathrm{~h}$ were prepared as followed: $38.79 \%$ of soya lecithin (dissolved in chloroform) was added to $15.1 \%$ of 
Tween ${ }^{\circledR} 80$ (dissolved in a methanol:chloroform (1:2) mixture) that was rota-evaporated at $68{ }^{\circ} \mathrm{C}$ to obtain a dry lipid film. The films were stored in a vacuum oven to eliminate traces of organic solvents prior reconstitution with the dissolved zolmitriptan $(9.8 \%)$ in $\mathrm{pH} 6$ buffer under stirring for $1 \mathrm{~h}$ at $90{ }^{\circ} \mathrm{C}$ at $60 \mathrm{rpm}$. After hydration of the film, the final formulation was annealed at room temperature for 2 hours, probe sonicated for $25 \mathrm{~min}$ with a pulse of $10 \mathrm{~min}$ and filtered through a $0.22 \mu \mathrm{m}$ nylon filter (Pitta et al., 2017). An initial particle size of $93.3 \mathrm{~nm}$ was obtained after lyophilization, particles were agglomerated and size was increased above $1 \mu \mathrm{m}$. This formulation was developed for intranasal administration due to the high permeability of the nasal epithelium and the quick absorption by this route; brain delivery was possible through the olfactory pathway. An in vitro release study of the optimized transferosomal formulation was performed exhibiting a $97 \%$ release after $10 \mathrm{~h}$ while the marketed nasal spray Zolmist ${ }^{\circledR}$ resulted in a $98 \%$ release in $4 \mathrm{~h}$. The bioavailability of the transferosomal formulation was found to be 1.72-fold higher than Zolmist ${ }^{\circledR}$.

Similary, a Box-Behnken design was employed in optimising raloxifene transferosomes for estrogen replacement therapy but utilising sodium deoxycholate as the edge activator. The investigated variables were the amount of phosphatidylcholine (100, 200 and 300 $\mathrm{mg})$ and edge activator $(15,35$ and $55 \mathrm{mg})$ along with the probe sonication time $(15,25$ and $35 \mathrm{~min}, 325 \mathrm{~W}$ ). The effect of these factors on the following three responses, entrapment efficiency, particle size and transdermal flux was investigated. The optimised formulation was prepared using the film evaporation method by dissolving the lipids $(89.23 \%)$, the raloxifene $(0.36 \%)$ and the edge activator $(10.41 \%)$ in a mixture of methanol and chloroform (1:2) and rota-evaporating the solvent mixture under vacuum at $40{ }^{\circ} \mathrm{C}$ until a dry lipid film was obtained. Overnight evaporation under vacuum to ensure no traces of solvents was necessary. Film rehydration using a PBS buffer (pH 6.5) by stirring for $1 \mathrm{~h}$ at $41-44{ }^{\circ} \mathrm{C}$ at $120 \mathrm{rpm}$ was performed. Transferosomes were annealed for 2-3 hours at room temperature, followed by probe sonication for 20-30 $\min (325 \mathrm{~W}$ ) and extrusion through 0.45 and $0.22 \mu \mathrm{m}$ polycarbonate membranes (Mahmood et al., 2014). The optimised transferosomes possessed a particle size of $134 \pm 9 \mathrm{~nm}$, with a drug entrapment of $91 \pm 4.9 \%$ and exhibited a transdermal flux of $6.5 \pm 1.1 \mu \mathrm{g} / \mathrm{cm}^{2} / \mathrm{h}$. Transferosomal permeation was 1.05 and 4-fold higher than ethosomal raloxifene (6.194 $\mu \mathrm{g} / \mathrm{cm}^{2} / \mathrm{h}$ ) and plain drug solution $\left(1.6 \mu \mathrm{g} / \mathrm{cm}^{2} / \mathrm{h}\right.$ ), respectively (Thakkar et al., 2016). 
A Box-Behnken design was also utilised in the optimization of valsartan transferosomes for hypertension employing sodium deoxycholate (DC) as edge activator. The effect of four variables on the drug encapsulation efficiency, permeation flux across the skin and particle size was investigated. The four variables were the following: i) amount of phosphatidylcholine (Phospholipon $90 \mathrm{G}$ at 75, 85 or $95 \mathrm{mg}$ ), ii) amount of edge activator $(5,15$ and $25 \mathrm{mg})$, iii) amount of drug $(40,60$ and $80 \mathrm{mg})$ and iv) sonication time $(15,25$ and $35 \mathrm{~min}$ ). The optimised formulation was prepared using a similar film evaporation method as described above. Upon "trading off" response variables, the final formulation composition contained phosphatidylcholine ( $85 \mathrm{mg})$, DC (15 mg), valsartan (60 mg), using a sonication time of 25 minutes. The particle size was $130 \pm 10 \mathrm{~nm}$ with a encapsulation entrapment of $85.77 \% \pm 2.97 \%$ and a transdermal flux across rat skin of $627.47 \pm 30.45 \mu \mathrm{g} / \mathrm{cm}^{2} / \mathrm{h}$. Results of in vivo antihypertensive activity indicated that the transferosomal formulation released the drug gradually over a period of time of $48 \mathrm{~h}$, which resulted in prolonged control of hypertension, 3.6-fold times greater than liposomal valsartan (Ahad et al., 2012b).

Sildenafil transferosomes were developed using a Plackett-Burman pre-screening design, allowing the investigation of the effect of a large number of factors with minimal number of experimental runs to elucidate which parameters were critical in the final characteristics of the transferosomes. Six variables on two different responses (particle size and entrapment efficiency) were investigated: i) drug:phospholipid molar ratio (1:2, 1:6 or 1:10); ii) phospholipid:edge activator ratio $(95: 5,85: 15$ or $72: 25)$; iii) edge activators with different HLB (Tween ${ }^{\circledR} 80$ or Span ${ }^{\circledR} 80$ ); iv) pH of the PBS rehydration buffer $(5.5,6.5$ or 7.5$)$; v) hydration time $(30,75$ or $120 \mathrm{~min})$ and vi) temperature during hydration $\left(2,11\right.$ or $\left.20^{\circ} \mathrm{C}\right)$. Drug, phospholipids and edge activator were dissolved in methanol and the solvent was evaporated in a rotatory evaporator under vacuum at $45^{\circ} \mathrm{C}$ until the lipid film was obtained. The flask was kept under vacuum overnight to ensure the complete solvent evaporation, prior rehydration with PBS of various $\mathrm{pH}$ over a range of times at different temperatures as described above. Finally, the formulation was bath sonicated for 30 minutes (Ahmed, 2015).

Surfactant HLB and temperature of the hydration medium had a positive effect on the vesicle size of the transferosomes, and hence, a decrease in the HLB led to an increase in particle size probably due to the affinity between edge activator and lipids. A higher temperature of the medium led to the formation of more stable smaller vesicles. Factors 
with a significant impact on entrapment efficacy were the drug:phospholipid ratio and the $\mathrm{pH}$ of the hydration medium. Increase in the entrapment efficacy was obtained using lower amount of lipids, which was atributed to the competition between the drug and the lipid in the bilayer of the transferosomes, which led to an exclusion of the drug inside the vesicle. As the drug's solubility decreased with increasing the $\mathrm{pH}$ of the hydration medium, a higher entrapment was obtained at higher $\mathrm{pH}$ due to a migration of the drug into the transferosomes cavity and lamellar layers (Ahmed, 2015). The in vitro permeation study showed that the optimized formulation had a 5-fold higher permeation compared with sildenafil suspension. The release profile of the transferosomal formulation was biphasic, with a burst release in the first 4 hours followed by a sustained release. This could be explained by the fact that a fraction of the drug was located on the surface of the transferosome which is rapidly released, while the encapsulated fraction within the transferosome followed a sustained release.

Apigenin transferosomes were optimised using a 3-level 3-factors Box-Behnken design. Phospholipid/edge activator ratio $(85: 15,90: 10,95: 5)$, sonication time $(10,20,30 \mathrm{~min})$ and rotation speed $(20,40,60 \mathrm{rpm})$ were the investigated factors, while particle size, drug loading and entrapment efficacy were the chosen responses. Phosphatidylcholine, Tween ${ }^{\circledR} 80$ and apigenin were dissolved in ethanol, which was later evaporated by rotary evaporation to form the lipid film in the flask. The film was hydrated at $45^{\circ} \mathrm{C}$ using PBS and a speed rotation of $60 \mathrm{rpm}$. The transferosomes were annelled at room temperature for 2 hours followed by probe sonication to reduce particle size. Drug retention in the skin after $24 \mathrm{~h}$ was 1.4-fold and 1.1-fold higher than the drug suspension and the marketed product (Jangdey et al., 2017), respectively.

Timolol transferosomes were optimised using a $2^{3}$ full factorial design (8 experimental runs). Two parallel designs were carried out using two different carriers either spray-dried lactose or mannitol. Phosphospholipid/edge activator ratio (3:1, 9:1), carrier/solvent mixture ratio $(5: 1,20: 1)$ and edge activator type (Span ${ }^{\circledR} 80$, Tween $\left.{ }^{\circ} 80\right)$ were the selected factors, while particle size, entrapment efficacy and release rate were the chosen responses. Phosphatidylcholine, edge activator and timolol were dissolved in a 2:1 mixture of chloroform:methanol (v/v). Later, the carrier (spray-dried lactose or mannitol) was added and the mixture was rota-evaporated for $30 \mathrm{~min}$ at $55{ }^{\circ} \mathrm{C}$ under reduced pressure. The resultant powder was kept in a dessicator overnight at room temperature to remove all traces of organic solvents. The optimised formulation containing spray-dried 
lactose showed a greater permeation (1.3-fold) after $24 \mathrm{~h}$ than the one containing mannitol (Morsi et al., 2017).

A $2^{3}$ full factorial design was also utilised for the development of optimised miconazole nitrate transferosomes entrapped in a Carpobol 934 gel for the treatment of candidiasis. Type of surfactant, total amount of lipids and phospholipid/surfactant ratio were the independent factors. The optimised formulation was consisted of soya lecithin and Span ${ }^{\circledR}$ 80 (ratio 90:10 w/w) and was loaded with clinical relevant amounts of miconazole (23.08 $\%)$. Treatment of Candida albicans infected rats with commercially available Daktarin ${ }^{\circledR}$ cream (2\%) allowed for reduction of the oedema and signs of inflammation; however, scarring was still present. In contrast, the transferosomal gel showed similar efficacy but with fewer signs of acanthosis (Qushawy et al., 2018).

Paclitaxel transferosomes were optimised using a 3-level 3-factors Box-Behnken design (15 experimental runs). The amounts of soya lecithin, cholesterol and $\mathrm{Span}^{\circledR} 80$ were the selected factors, while entrapment efficiency, particle size and cumulative drug permeation were the investigated responses. Soya lecithin, paclitaxel and cholesterol were dissolved in a mixture of ethanol and chloroform, followed by the addition of Span ${ }^{\circledR}$ 80. This mixture was probe sonicated for $30 \mathrm{~min}$ and later evaporated to dryness in a water bath at $60^{\circ} \mathrm{C}$. The resulting film was hydrated with $200 \mathrm{ml}$ of phosphate buffer $\mathrm{pH}$ 6.8 (Pathak et al., 2016). The gel formulation of paclitaxel encapsulated within transferosomes showed a 3.4-fold higher permeation than the control gel (freely dispersed paclitaxel in carbopol gel matrix) after $24 \mathrm{~h}$.

Insulin transferosomes were optimised using a $2^{3}$ full factorial design ( 8 experimental runs). Phosphatidylcholine/cholesterol ratio (8:3, 10:1 w:w), lipids/edge activator ratio $(1: 1,1.47: 1 \mathrm{w}: \mathrm{w})$ and Tween ${ }^{\circledR} 80 /$ sodium deoxycholate ratio $(4: 6,7: 3 \mathrm{w}: \mathrm{w})$ were the selected factors. Phosphatidylcholine, cholesterol and Tween ${ }^{\circledR} 80$ were placed inside a flask and dissolved in a mixture of diethyl ether:chloroform (3:1 v:v). The flask was kept at room temperature for $24 \mathrm{~h}$ until the film was formed. Insuline solution $(1.4 \mathrm{mg} / \mathrm{ml}$ in water) was added to the flask and probe sonicated $(20 \mathrm{KHz}, 2 \mathrm{~min})$. After that, the film was hydrated using sodium deoxycholate in PBS pH 7.4 and sonicated for $2 \mathrm{~min}$. Dimethyl sulfoxide (2\% v/v) was added as chemical permeation enhancer and later passed through Watman ${ }^{\circledR}$ filter paper $\left(\mathrm{N}^{\circ} .40\right)$. The transferosomal suspension was transferred to $5 \%$ w/v methylcellulose gel (Malakar et al., 2012). Optimised formulation 
had a 1.3-fold higher permeation through porcine ear skin when applied in the presence of iontophoresis.

A $3^{4}$ design was utilised to optimise resveratrol transferosomes entrapped into a Carbopol 934-Poloxamer 407 gel for intranasal administration in the treatment of Alzheimer's disease. The following independent factors were studied: phosphatidyl choline/permeation enhancer excipient ratio (7:3, 8:2, 9:1, w:w), (Phosphatidyl choline+permeation enhancer excipient)/edge activator ratio $(2: 1,3: 1,4: 1$, w:w), type of edge activator (Tween ${ }^{\circledR}$ 80, sodium deoxycholate or Cremophor ${ }^{\circledR}$ RH 40) and type of permeation enhancer excipient (Transcutol ${ }^{\circledR}$, oleic acid or ethanol). Particle size, polydispersity index, zeta-potential and entrapment efficiency were the selected responses. Resveratrol (10 mg), edge activator and phosphatidylcholine were dissolved in a 2:1 (v:v) chloroform:methanol mixture, vortexed for $10 \mathrm{~min}$ and later evaporated in a diseccator for 24 hours. The film was then hydrated with nasal simulated fluid $(10 \mathrm{ml})$ at $\mathrm{pH} 5.5$ which contained the permeation enhancer. The vesicles were formed and then annelled for 2 hours at room temperature. The mixture was then probe sonicated (20 min) and extruded through a $0.22 \mu \mathrm{m}$ filter to reduce particle size. The transferosomal suspension was centrifuged $\left(3 \mathrm{~h}, 20000 \mathrm{rpm}, 4{ }^{\circ} \mathrm{C}\right)$ to be separated and then reconstituded with nasal simulated fluid. The transferosomal gel was formed by adding Carbopol 934 and then Poloxamer 407 to the reconstituted transferosomes. The mixture was stirred until a clear solution was obtained. Two drops of triethanolamine were finally added to adjust the $\mathrm{pH}$ and form the gel. Optimised transferosomes resulted in 4.5 -fold more permeable than resveratrol suspension across sheep nasal mucosa (Salem et al., 2019).

Overall, it can be concluded that pre-screening fractional designs such as PlackettBurman or Taguchi are useful DoE at the first stages during the development of a novel transferosomal formulation in order to understand what are the key parameters affecting the particle size, drug loading and release. However, full factorial designs and specifically those including 3-levels and 3-factors are more interesting when the key factors are already known and a detail optimisation is carried out. It is worthy nothing that at labscale, the Critical Material Attributes (CMAs) such as amount of lipids, drug and edge activator play a more relevant role on the Critical Quality Attributes (CQAs) of the transferosomal formulation (mainly particle size and drug entrapment). However, Critical 
Process Parameters (CPPs) such as reconstitution volume, stirring and sonication time are highly important during the scale-up of the formulations. 


\section{Scale-up: from bench to industrial manufacturing}

The film evaporation method is the classical strategy to produce transferosomes at lab scale (Ahmed, 2015; Mahmood et al., 2014; Pitta et al., 2017). Experience in utilising this technique for industrial scale-up of liposomes and ethosomes is challenging and hampers the clinical traslation from bench to market of these nanomedicines. The main reason is the need for small batch sizes which increases manufacturing costs as well as the time needed to produce necessary quantities of the optimal formulation (Wagner and VorauerUhl, 2011). Several techniques have been implemented in industry to obtain transferosomes at a larger scale based on lessons learned on liposomal industrial manufacturing (Table 3 \& Fig. 6).

In homogenization/extrusion techniques, rehydrated films are subjected to constant pressure changes to break down multilaminar vesicles instead of sonication prior to the mixture is passed through different orifices to obtain transferosomes of different sizes (Wagner and Vorauer-Uhl, 2011). This method is easy to scale-up and the reduction of particle size remains reproducible; however, the process is time and resource consuming.

The ethanol injection method is based on the addition of ethanol into the aqueous phase. By that, the lipid molecules precipitate and form bilayer planar fragments, which themselves form lipid vesicles and entrap the aqueous media. This method is easy to scale-up, just by increasing the volume of the vessels and usually allows to obtain vesicles with higher entrapment efficacy and higher stability. The particle size can be tunned by controlling the ratio between lipids and edge activator and also by adjusting the whole diameter of the injection tool, the pressure of injection and the flow rate of the aqueous phase (Wagner and Vorauer-Uhl, 2011).

Protransferosome-transferosome method consists of the preparation of in situ transferosomes. The transferosome can be prepared using the same lab scale methods above mentioned (Davidson et al., 2016). The transition from a protransferosome to a transferosome takes place by diluting the formulation using an aqueous phase (Wagner and Vorauer-Uhl, 2011). This method is easy to scale-up and the stability of the formulation is usually acceptable.

Microfluidics can be applied in the manufacturing of transferosomes using different techniques: electroformation, which consists on the hydration of a lipid film in the 
presence of an alternating current (AC) electric field (Girard et al., 2004); pulsed jetting, which relies on a controlled pulsatile liquid jet directed into unilamellar lipid bilayer formed between two aqueous phases (Stachowiak et al., 2008); double emulsion transfer, which consists on the templating of the oil phase by the water droplets in this phase, and then transferring it to an aqueous phase by centrifugation or repeated washing; ice droplet hydration, which consists on a monodisperse W/O emulsion with an average droplet size prepared by microchannel emulsification. These droplets are frozen, separated and replaced by a surfactant and then the solvent is evaporated (Sugiura et al., 2008); hydrodynamic forces, which consist on a sample which is forced to pass through a small channel at a high flow speed (Golden et al., 2012).

The formation of transferosomes is based on the diffusion of the different molecular species (usually alcohol and water, but also lipids) at the liquid interface between the solvent (alcohol) and the water. The alcohol diffuses into the aqueous phase until the solvent concentration decreases to a critical level, below the solubility limit of the lipids. This fact triggers the formation of the transferosomes by self-assembly. It is believed that the constant diffusion of alcohol and water across the interface leads to lipid precipitation, resulting in the formation of lipid vesicles. This technique has demonstrated a good uniformity in the production of particles as allows a direct control of their size by doing fine adjustments of the volumetric flow rate ratio between the lipid and aqueous phase or the total flow rate (Carugo et al., 2016). 


\section{Transferosomes under clinical trials}

Several transferosomes are currently under clinical trials including drugs or phytocompounds as active pharmaceutical ingredients (API).

Papaverine, a phytocompound obtained from Papaver somniferum known to produce relaxation of smooth muscles and dilation of blood vessels, is currently under clinical trials for the treatment of erectile dysfunction (Ali et al., 2015). The composition of this transferosomal formulation is soya phosphatidyl choline (50 mg), cholesterol (30 mg) and sodium deoxycholate, $\mathrm{Span}^{\circledR} 60$ and $\mathrm{Brij}^{\circledR} 35$ (polyoxyethylene lauryl ether) used as edge activators (25, 50 and $100 \mathrm{mg}$ respectively) (Ali et al., 2015).

A Phase I placebo-controlled study was performed including 9 men between 32 and 60 years old from Minia University Hospital (Egypt) with at least 1-month history of erectile dysfunction. Participants received treatment with papaverine either encapsulated within transferosomes or mixed with hydroxypropyl methylcellulose (HPMC) hydrogel. The placebo group was treated with a HPMC hydrogel without the drug. The study took place during a 11-day period (Ali et al., 2015) that involved four sessions. During the $1^{\text {st }}$ session (day 1), the hydrogel was applied. During the $2^{\text {nd }}$ session (day 4): the hydrogel was applied again; biochemical and analytical measurements including blood pressure, heart rate, cavernous artery diameter and peak systolic flow were measured before and 1 hour after the administration of the gel. During the $3^{\text {rd }}$ session (day 8): the application of hydrogel was also performed and erections were evaluated according to curvature of the penis. Finally, during the $4^{\text {th }}$ session (day 11): penis and scrotum were evaluated to check any skin changes.

The application of the transferosomal gel resulted in a $47 \%$ statistically significant increase in the cavernous artery diameter. An increase in the diameter higher than $65 \%$ happened in three of the volunteers treated with the transferosomal papaverine gel, but only in one patient treated with the free form gel. The application of the papaverine gels triggered a decrease in blood pressure in the hypertensive group and positive response to treatment appeared in $44 \%$ of the volunteers. No undesirable effects were seen after the application of the gel; there was no evidence of skin irritation, erythematous rash, facial flushing, dizziness or pain in the area of application, ensuring the safety of the formulation (Ali et al., 2015). 


\section{Marketed transferosomes}

To the best of our knowledge, Diractin ${ }^{\circledR}$, containing ketoprofen, has been the only transferosomal formulation to reach the market licensed by the Swiss Regulatory Agency (SwissMedic) in 2007. This formulation was indicated as a painkiller in knee osteoarthritis (Rother et al., 2009). Transferosomes were able to deliver ketoprofen to deeper tissues, including muscle, compared to conventional anti-inflammatory gels (Kneer et al., 2009). However, six months after the approval, the product was withdrawn by EMA as deemed only marginally superior efficacy compared to ketoprofen freevehicle (Kneer et al., 2013; Rajan et al., 2011). One of the main reasons that can explain the withdrawal from the market is the higher-cost associated with the manufacturing process of transferosomes compared to conventional gels. The higher manufacturing cost is linked with a greater medicine price. However, the marginal benefit obtained from the transferosomal formulation in terms of permeability is not enough to justify a higher treatment cost. When formulated appropiately, transferosomes have a greater permeability capacity than other topical dosage form and drug delivery systems. Its higher cost can be justified in certain diseases that require higher permeability into deeper tissues, even the bloodstream, or when formulating challenging molecules that possess extremely poor permeability properties. In those cases, the clinical benefit from using transferosomes would be greater and hence, the economic cost can be justified. Ketoprofen is a lipophilic drug ( $\log \mathrm{P}=3.61$ (DrugBank, 2019)) with low molecular weight $(254 \mathrm{~g} / \mathrm{mol})$. Hence, its permeability across the skin is acceptable and hence, a conventional gel delivers enough drug to elicit a pharmacological effect. For this reason, a transferosomal ketoprofen formulation was not ideal as the room for improvement was limited.

\section{Future perspectives and concluding remarks}

Lipid nano-carriers are highly researched and utilised technologies for transcutaneous and transdermal delivery across the stratum corneum. Transferosomes have shown to have an important advantage over liposomes and niosomes due to their ultra-deformable properties conferred by the edge activator that allows them to reach deeper layers inside the skin via intercellular and paracellular routes across the corneocytes. QbD can be utilised to guide the development of optimal transferosomal composition as well as the effect of manufacturing processing. Work is still needed in translating lab scale 
manufacture of transferosomes to industrial processess ensuring that final products maintain their composition, stability, loading, and particle size. Clinical studies so far confirm the tolerability of the transferosomal formulations, however, work is still needed to develop protocols in combining this technology with other techniques used for permeation enhancement such as iontophoresis, electroporation and microneedles to facilitate further drug delivery of drugs across the skin (Prausnitz and Langer, 2008); although very few reports has been found in literature about the combination of these techniques with transferosomes, a synergistic effect on the skin permeability could be achieved bearing in mind their mechanism of action. In the case of iontophoresis, the increase in permeability is obtained by providing an electric driving force for transport the drug across the SC (Malakar et al., 2012). Small and hydrophilic drugs are the ideal candidates for this technique based on the principle that in a given electric field, cations (positively charged drugs) are repelled by a positive electrode called anode and are directed towards the catode, while anions (negatively charged molecules) follow the anode after being repelled by the negative electrode, catode (Karpinski, 2018). The combination of transferosomes and electroporation can be another viable option for increasing the skin permeation based on the formation of temporarily aqueous pores in cell membranes after the application of high voltage pulses (Ita, 2016). Even though, this technique has a broader application for different lipophilicites and sizes including high molecular weight biopharmaceuticals, the voltage applied could also disturbe the integrity of the transferosomes and hence, limiting their skin penetration. In the case of microneedles, the formation of micron-scale pathways into the skin, as well drive nanomedicines directly into the skin can potentially enhance the delivery of transferosomes across the SC (Wu et al., 2019; Yang et al., 2019). In this sense, the manufacturing of dissolvable microneedles containing transferosomes immobilised within a solid matrix could resolve the long term stability issues of the transferosomes in liquid media. In conclusion, there are plenty of options to explore in order to improve the capabilities of transferosomes and close the gap between lab-scale manufacturing and clinical medicines based on transferosomes. Apart from all the mentioned studies, transferosomes have been recently formulated to deliver proteins, such us the growth hormone (Azimi, 2019) or oligopeptides (Jiang et al., 2018). 
10. Figure legends

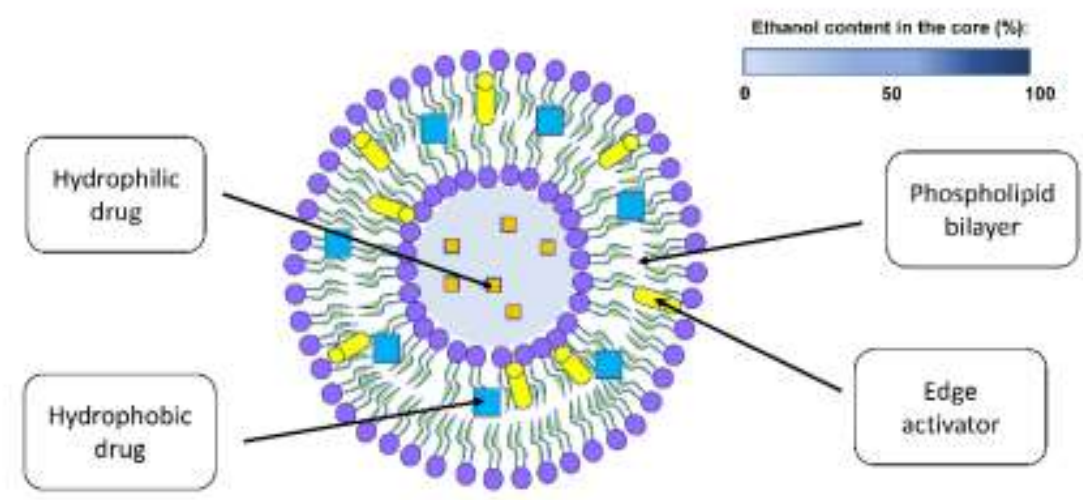

Figure 1. Schematic representation of the composition of a transferosome including the main components: hydrophilic and hydrophobic drugs, phospholipids and edge activator as well as the internal core with the mixture of water and ethanol. 


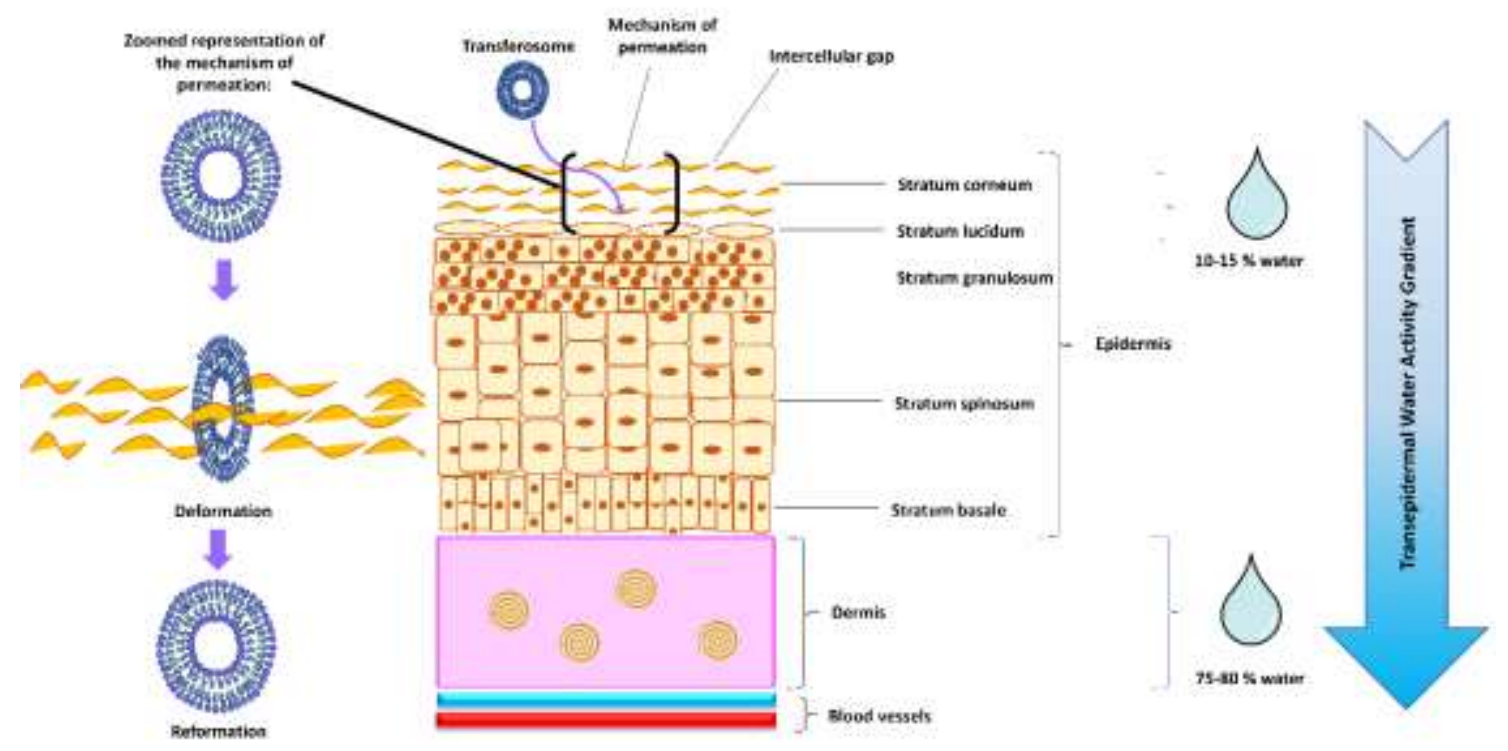

Figure 2. Schematic representation of the mechanism of penetration of transferosomes across the skin. After topical administration, the transferosome is exposed to a transdermal osmotic gradient due to the difference in water content between the stratum corneum and the viable epidermis. This gradient triggers the evaporation of the liquid of the transferosome and make favorable its deformation and penetration across the stratum corneum towards deeper and more aqueous areas of the skin in order to rehydrate. 

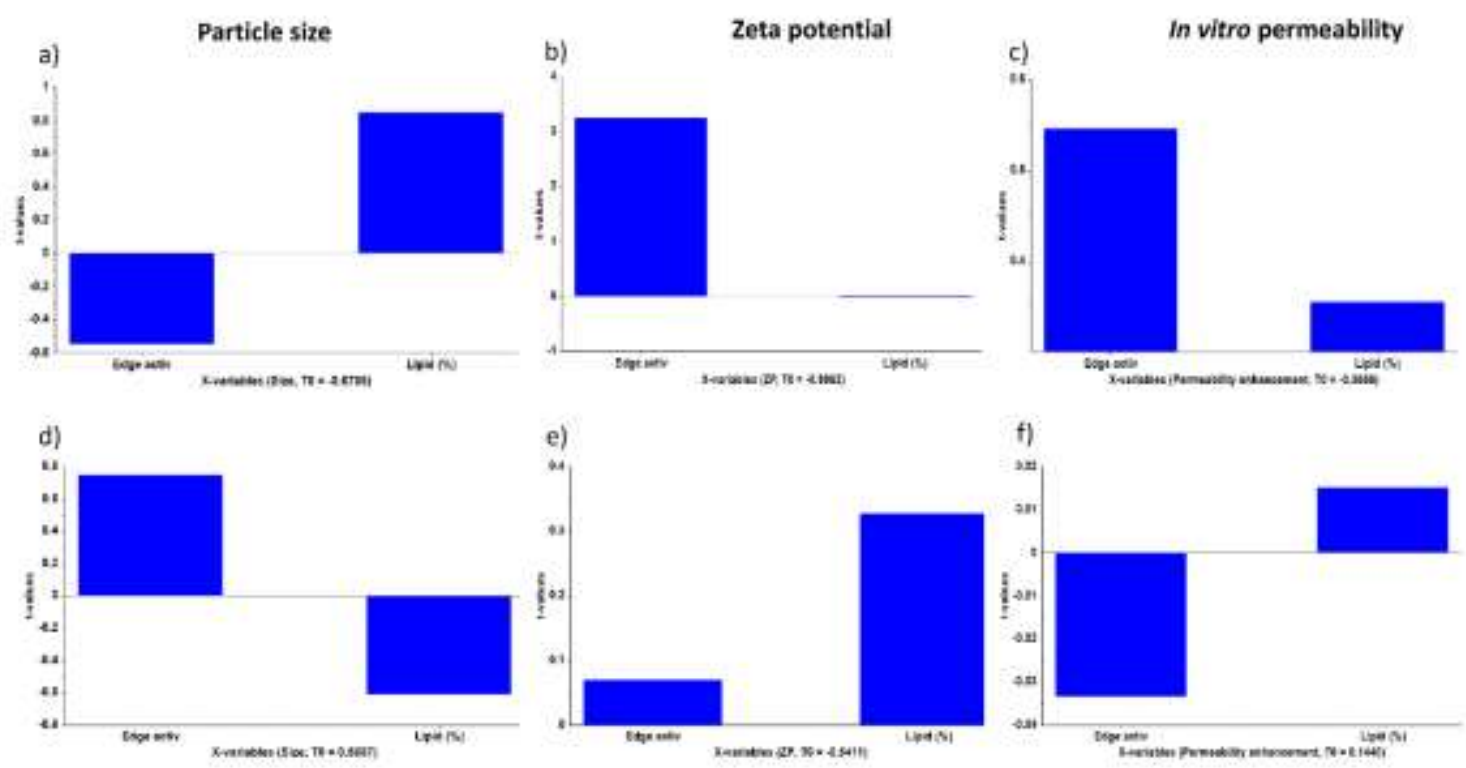

Figure 3. Multilinear regression analysis (using Unscrambler ${ }^{\circledR}$ ) of the compiled data illustrated in Table 1. The effect of the percentage of lipids and edge activator on the particle size, zeta-potential and in vitro permeability was evaluated. Those formulations containing an ionic edge activator (sodium deoxycholate) were analyzed separately from those formulated with a non-ionic surfactant (Tween ${ }^{\circledR} 80$ and $\operatorname{Span}^{\circledR}$ 80). Key: sodium deoxycholate used as edge activator (a, b and c); Span ${ }^{\circledR}$ 80 and Tween $^{\circledR} 80$ used as edge activator $(d, e, f)$. 
A)

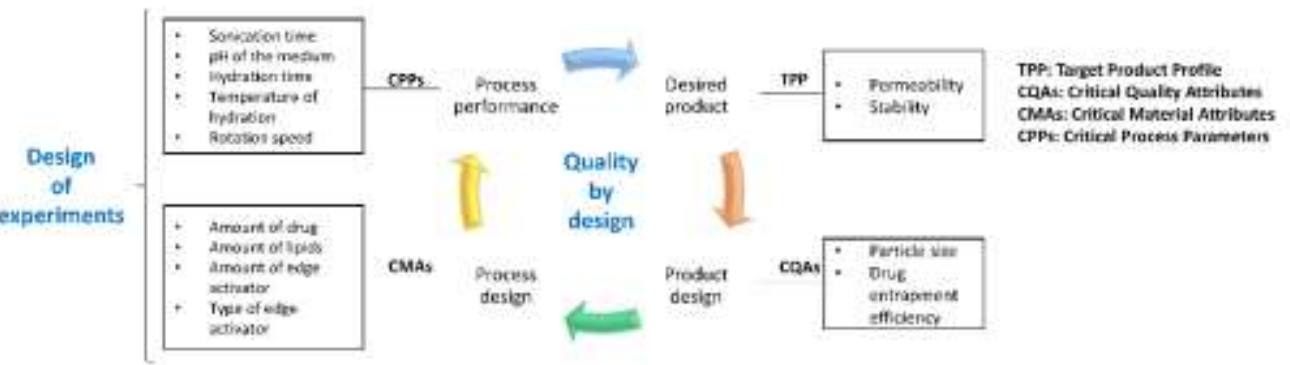

B)

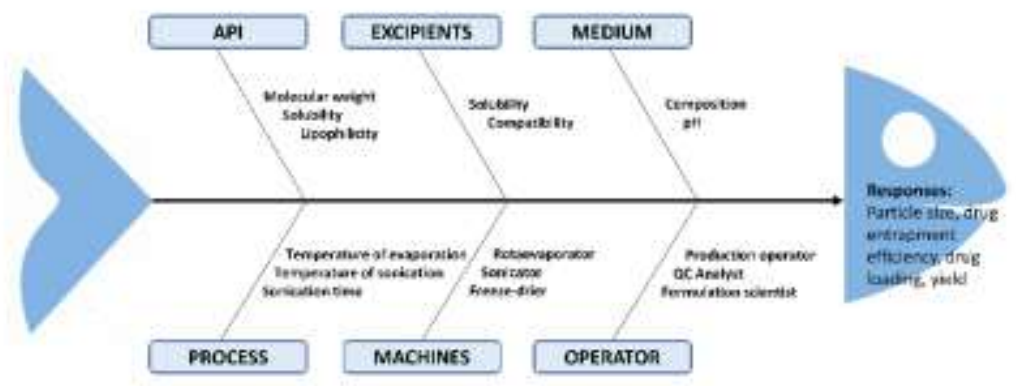

Figure 4. A) Steps to follow in the QbD process of the manufacturing of transferosomes: including target product profile (TPP), critical quality attributes (CQAs), critical material attributes (CMAs), and critical process parameters (CPPs). B) Ishiwaka diagram representing the most critical parameters in the optimization of transferosomes. 
A)

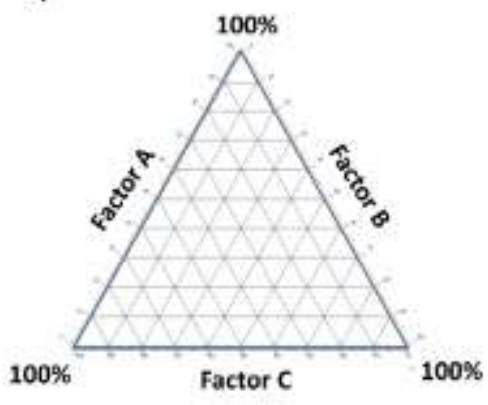

B)

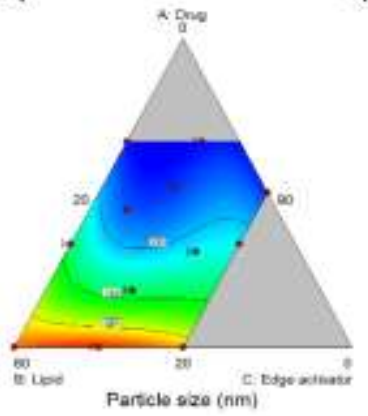

c)

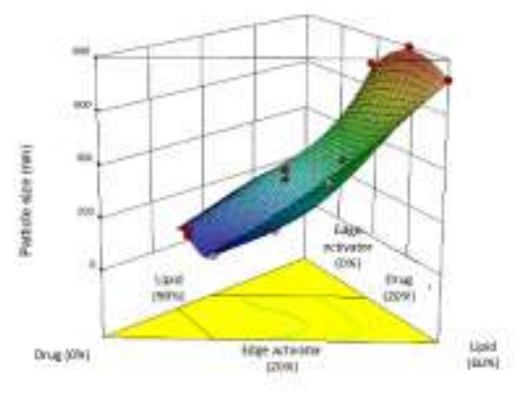

Figure 5. Application of QbD in the optimization of transferosomes. Key: A) Schematic representation of a ternary diagram. B) Constrained mixture design (contour plot) for optimization of particle size where the factors $\mathrm{A}, \mathrm{B}$, and $\mathrm{C}$ represent the amount of drug, lipid and edge activator in the transferosomal formulation. C) 3D surface plot exhibiting the relationship between the effect of the transferosome composition and particle size. 


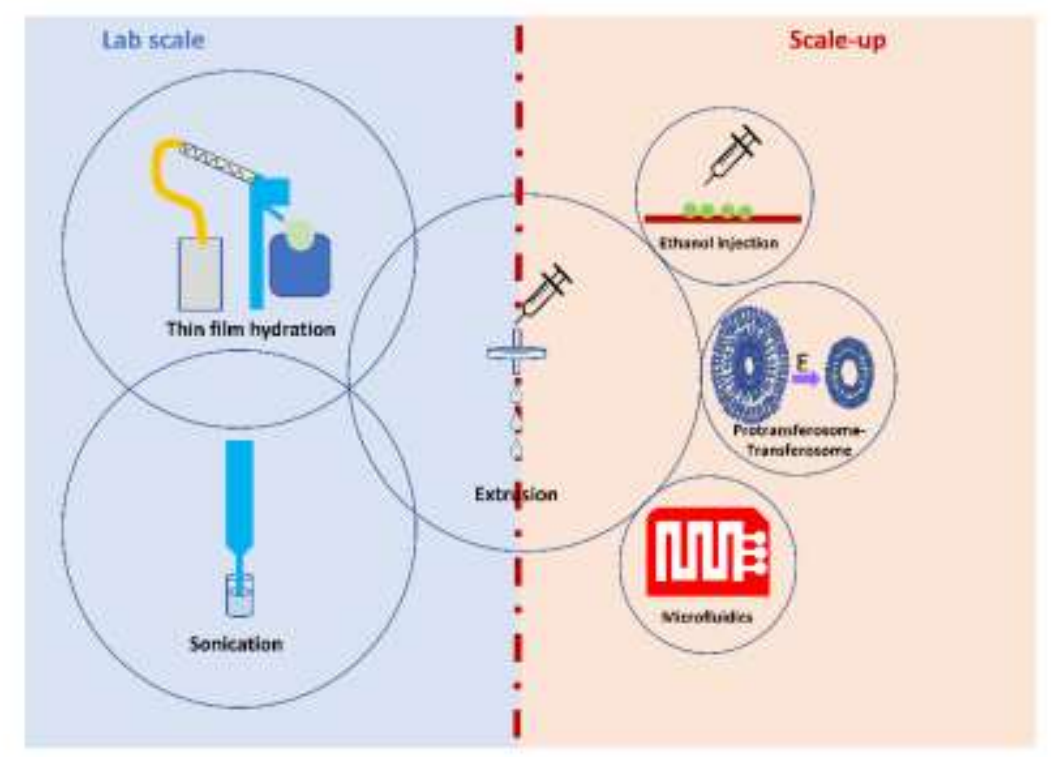

Figure 6. Schematic representation of lab and industrial scale techniques in the manufacturing of transferosomes, including thin film hydration method, sonication, extrusion, sequential filtration, homogenization, ethanol injection method, protransferosome-transferosome method and microfluidics. 
Table 1. Summary of transferosomal formulations under preclinical research. The main components of the formulations are illustrated in the table: phospholipid, edge activator and drug. Key: DSPE: 1,2Distearoyl-sn-glycero-3-phosphoethanolamine; DC, sodium deoxycholate; PANAM G3, polyamido amide dendrimer third generation.

\begin{tabular}{|c|c|c|c|c|c|c|c|c|c|c|}
\hline $\begin{array}{c}\text { Drug } \\
(\%)\end{array}$ & $\begin{array}{c}\text { Thera } \\
\text { peutic } \\
\text { use }\end{array}$ & $\begin{array}{c}\text { Edge } \\
\text { activator } \\
(\%)\end{array}$ & Lipids (\%) & Method & $\begin{array}{l}\text { Parti } \\
\text { cle } \\
\text { size } \\
(\mathrm{nm})\end{array}$ & $\begin{array}{c}\text { Zeta } \\
\text { potenti } \\
\text { al } \\
(\mathbf{m V})\end{array}$ & $\begin{array}{c}\text { In vitro } \\
\text { behaviour }\end{array}$ & $\begin{array}{c}\text { In vivo } \\
\text { behaviour }\end{array}$ & Safety & $\begin{array}{c}\text { Refer } \\
\text { ence }\end{array}$ \\
\hline & \multicolumn{10}{|c|}{ Phytocompounds } \\
\hline $\begin{array}{l}\text { Sinomeni } \\
\text { ne } \\
\text { (Sinomeni } \\
\text { um } \\
\text { acutum) } \\
(20.3)\end{array}$ & $\begin{array}{l}\text { Rheum } \\
\text { atoid } \\
\text { arthritis }\end{array}$ & $\begin{array}{c}\text { Mixed } \\
\text { monoterp } \\
\text { enes } \\
\text { (limonen } \\
\text { e:citrol, } \\
\text { 1:1, w:w) } \\
\text { (4) }\end{array}$ & $\begin{array}{c}\text { Egg } \\
\text { Phosphatidyl } \\
\text { choline (61) } \\
\text { + DSPE- } \\
\text { PEG2000 } \\
(3.7)+ \\
\text { Cholesterol } \\
(10)+ \\
\text { Vitamin E } \\
(1)\end{array}$ & $\begin{array}{l}\text { Ethanol } \\
\text { injection } \\
\text { method } \\
\text { followed } \\
\text { by } \\
\text { extrusion }\end{array}$ & 109 & -18.9 & $\begin{array}{c}\text { Mixed } \\
\text { monoterpenes } \\
\text { edge activator } \\
\text { transferosomes } \\
\text { showed 1.5- fold } \\
\text { higher in vitro } \\
\text { permeability }\end{array}$ & $\begin{array}{l}\text { Transfero } \\
\text { somes } \\
\text { showed a } \\
\text { steady- } \\
\text { state } \\
\text { concentrat } \\
\text { ion 8-fold } \\
\text { greater } \\
\text { than } \\
\text { liposomes }\end{array}$ & $\begin{array}{l}\text { The } \\
\text { formulati } \\
\text { on is well } \\
\text { tolerated } \\
\text { with no } \\
\text { reported } \\
\text { irritation } \\
\text { in the skin }\end{array}$ & $\begin{array}{l}\text { (Wan } \\
\text { g et } \\
\text { al., } \\
\text { 2017) }\end{array}$ \\
\hline \multirow[t]{2}{*}{$\begin{array}{l}\text { Apigenin } \\
\text { (flavone } \\
\text { found in } \\
\text { many } \\
\text { plants) } \\
(0.05)\end{array}$} & $\begin{array}{l}\text { Leukae } \\
\text { mia }\end{array}$ & $\begin{array}{l}\text { Tween }{ }^{\circledR} \\
80(10)\end{array}$ & $\begin{array}{c}\text { Phosphatidyl } \\
\text { choline } \\
(89.95)\end{array}$ & $\begin{array}{l}\text { Thin film } \\
\text { hydration } \\
\text { technique } \\
\text { followed } \\
\text { by } \\
\text { sonication }\end{array}$ & 35 & -14.3 & $\begin{array}{c}\text { Optimised } \\
\text { transferosomes } \\
\text { showed } 1.2 \text {-fold } \\
\text { higher in vitro } \\
\text { permeation than } \\
\text { the drug } \\
\text { suspension and } \\
\text { the marketed } \\
\text { product }\end{array}$ & $\begin{array}{l}\text { Not } \\
\text { reported }\end{array}$ & $\begin{array}{c}\text { Not } \\
\text { reported }\end{array}$ & $\begin{array}{l}\text { (Jangd } \\
\text { ey et } \\
\text { al., } \\
2017)\end{array}$ \\
\hline & \multicolumn{10}{|c|}{ Chemically synthetized drugs } \\
\hline $\begin{array}{l}\text { Eprosarta } \\
\mathrm{n} \\
\text { mesylate } \\
\quad(\text { Not } \\
\text { reported) }\end{array}$ & $\begin{array}{l}\text { Hypert } \\
\text { ension }\end{array}$ & $\begin{array}{l}\text { DC }(25) \\
\text { or Span }{ }^{\circledR} \\
80(15)\end{array}$ & $\begin{array}{c}\text { Phosphatidyl } \\
\text { choline }(75 \\
\text { or } 85)\end{array}$ & $\begin{array}{l}\text { Thin film } \\
\text { hydration } \\
\text { technique } \\
\text { followed } \\
\text { by } \\
\text { sonication } \\
\text { and } \\
\text { extrusion }\end{array}$ & $\begin{array}{l}108 \\
\text { (with } \\
\text { DC) } \\
160 \\
\text { (with } \\
\text { Span } \\
\text { ®) }\end{array}$ & $\begin{array}{c}-14 \\
\text { (with } \\
\text { DC) or } \\
-10 \\
\text { (with } \\
\text { Span® } \\
\text { ) }\end{array}$ & $\begin{array}{c}\text { Enhancement } \\
\text { permeation ratio } \\
\text { of } 16.8 \text { (for DC) } \\
\text { or 9-fold (for } \\
\text { Span }{ }^{\circledR} 80 \text { ) over } \\
\text { traditional } \\
\text { liposomes }\end{array}$ & $\begin{array}{c}\text { Not } \\
\text { reported }\end{array}$ & $\begin{array}{c}\text { Not } \\
\text { reported }\end{array}$ & $\begin{array}{l}\text { (Ahad } \\
\text { et al., } \\
\text { 2017) }\end{array}$ \\
\hline $\begin{array}{c}\text { Valsartan } \\
(37.6)\end{array}$ & $\begin{array}{l}\text { Hypert } \\
\text { ension }\end{array}$ & DC (9.4) & $\begin{array}{l}\text { Phosphatidyl } \\
\text { choline (53) }\end{array}$ & $\begin{array}{l}\text { Thin film } \\
\text { hydration } \\
\text { technique } \\
\text { followed } \\
\text { by } \\
\text { sonication }\end{array}$ & 130 & $\begin{array}{c}\text { Not } \\
\text { reporte } \\
\mathrm{d}\end{array}$ & $\begin{array}{c}\text { Enhancement } \\
\text { permeation ratio } \\
\text { of } 33 \text { over drug } \\
\text { entrapped within } \\
\text { liposomes }\end{array}$ & $\begin{array}{c}\text { Blood } \\
\text { pressure } \\
\text { was 3.5- } \\
\text { fold lower } \\
\text { after } \\
\text { using } \\
\text { transferos } \\
\text { omes } \\
\text { when } \\
\text { compared } \\
\text { to the oral } \\
\text { suspensio } \\
n\end{array}$ & $\begin{array}{c}\text { Not } \\
\text { reported }\end{array}$ & $\begin{array}{c}\text { (Ahad } \\
\text { et al., } \\
2012 \mathrm{a} \\
\text { ) }\end{array}$ \\
\hline $\begin{array}{l}\text { Timolol } \\
\text { (Not } \\
\text { reported) }\end{array}$ & $\begin{array}{l}\text { Hypert } \\
\text { ension }\end{array}$ & $\begin{array}{l}\text { Span }{ }^{\circledR} 80 \\
(\text { Not } \\
\text { reported) }\end{array}$ & $\begin{array}{c}\text { Phosphatidyl } \\
\text { choline (Not } \\
\text { reported)+ } \\
\text { spray-dried } \\
\text { lactose or } \\
\text { mannitol } \\
\text { (Not } \\
\text { reported) } \\
\text { (Spray-dried } \\
\text { lactose and } \\
\text { mannitol are } \\
\text { not lipids, } \\
\text { however, } \\
\text { they are used } \\
\text { in these } \\
\text { formulations } \\
\text { as carriers) }\end{array}$ & $\begin{array}{c}\text { Film } \\
\text { deposition } \\
\text { on carrier } \\
\text { method }\end{array}$ & $\begin{array}{c}2800 \\
\text { (with } \\
\text { spray } \\
- \\
\text { dried } \\
\text { lacto } \\
\text { se), } \\
1640 \\
\text { (with } \\
\text { mann } \\
\text { itol) }\end{array}$ & $\begin{array}{c}\text { Not } \\
\text { reporte } \\
\mathrm{d}\end{array}$ & $\begin{array}{c}\text { Using spray- } \\
\text { dried lactose as } \\
\text { a nano-carrier } \\
\text { showed an in } \\
\text { vitro permeation } \\
\text { 1.3-fold higher } \\
\text { than the } \\
\text { formulation with } \\
\text { mannitol }\end{array}$ & $\begin{array}{c}\text { Protransfe } \\
\text { rosomal } \\
\text { formulati } \\
\text { on } \\
\text { showed a } \\
\mathrm{C}_{\max } 2.6- \\
\text { fold lower } \\
\text { than the } \\
\text { oral } \\
\text { solution } \\
\text { and a } \\
\text { delay in } \\
\text { the } \mathrm{t}_{\mathrm{max}} \\
\text { from } 1.5 \\
\text { hours to } \\
24 \text { hours }\end{array}$ & $\begin{array}{l}\text { Well } \\
\text { tolerated. } \\
\text { No signs } \\
\text { of } \\
\text { erythema } \\
\text { or edema }\end{array}$ & $\begin{array}{l}\text { (Mors } \\
\text { i et } \\
\text { al.. } \\
2017)\end{array}$ \\
\hline $\begin{array}{l}\text { Cytarabin } \\
\text { e (14.5) }\end{array}$ & $\begin{array}{l}\text { Leukae } \\
\text { mia }\end{array}$ & $\begin{array}{c}\text { Sodium } \\
\text { deoxycho } \\
\text { late (13) }\end{array}$ & $\begin{array}{c}\text { Phosphatidyl } \\
\text { choline } \\
(72.5)\end{array}$ & $\begin{array}{l}\text { Thin film } \\
\text { hydration } \\
\text { technique }\end{array}$ & 114 & $\begin{array}{c}\text { Not } \\
\text { reporte } \\
\mathrm{d}\end{array}$ & $\begin{array}{c}\text { Flux across rat } \\
\text { skin of } \\
192.8 \pm 3.6\end{array}$ & $\begin{array}{c}\text { Plasma } \\
\text { concentrat } \\
\text { ion of }\end{array}$ & $\begin{array}{l}\text { Less skin } \\
\text { irritation } \\
\text { that drug }\end{array}$ & $\begin{array}{l}\text { (Raj et } \\
\text { al., } \\
2016)\end{array}$ \\
\hline
\end{tabular}




\begin{tabular}{|c|c|c|c|c|c|c|c|c|c|c|}
\hline & & & & $\begin{array}{l}\text { followed } \\
\text { by } \\
\text { sonication } \\
\text { and } \\
\text { extrusion }\end{array}$ & & & $\begin{array}{l}\mu \mathrm{g} / \mathrm{cm}^{2} / \mathrm{h}(5- \\
\text { fold and } 17 \text {-fold } \\
\text { higher than } \\
\text { liposomes and } \\
\text { drug in solution) }\end{array}$ & $\begin{array}{c}\text { transferos } \\
\text { omes was } \\
11.7 \text {-fold } \\
\text { higher } \\
\text { than rigid } \\
\text { liposomes } \\
\text { after } 8 \\
\text { hours. } \\
\text { After } 1 \\
\text { hour and } \\
24 \text { hours, } \\
\text { cytarabine } \\
\text { was only } \\
\text { observabl } \\
\text { e in the } \\
\text { case of } \\
\text { transferos } \\
\text { omes }\end{array}$ & $\begin{array}{c}\text { in } \\
\text { solution } \\
\text { and } \\
\text { conventio } \\
\text { nal } \\
\text { liposomes }\end{array}$ & \\
\hline $\begin{array}{l}\text { Pentoxify } \\
\text { lline } \\
(9.52)\end{array}$ & $\begin{array}{l}\text { Intermi } \\
\text { ttent } \\
\text { claudic } \\
\text { ation }\end{array}$ & $\begin{array}{l}\text { Sodium } \\
\text { cholate } \\
(14.29)\end{array}$ & $\begin{array}{c}\text { Phosphatidyl } \\
\text { choline } \\
(76.19)\end{array}$ & $\begin{array}{l}\text { Vortexing- } \\
\text { sonication } \\
\text { method } \\
\text { followed } \\
\text { by } \\
\text { extrusion }\end{array}$ & 690 & -34.9 & $\begin{array}{c}\text { Transdermal } \\
\text { permeability of } \\
\text { transferosomes } \\
\text { was } 8.5 \text {-fold } \\
\text { higher than drug } \\
\text { in aqueous } \\
\text { solution }\end{array}$ & $\begin{array}{c}\text { Transder } \\
\text { mal } \\
\text { administr } \\
\text { ation of } \\
\text { pentoxifyl } \\
\text { line } \\
\text { transferos } \\
\text { omes } \\
\text { resulted in } \\
\text { 1.2-fold } \\
\text { lower } \\
\text { than oral } \\
\text { administr } \\
\text { ation of } \\
\text { pentoxifyl } \\
\text { line } \\
\text { tablets }\end{array}$ & $\begin{array}{l}\text { Not } \\
\text { reported }\end{array}$ & $\begin{array}{l}\text { (Al } \\
\text { Shuw } \\
\text { aili et } \\
\text { al., } \\
2016)\end{array}$ \\
\hline $\begin{array}{l}\text { Asenapin } \\
\text { e maleate } \\
(5)\end{array}$ & $\begin{array}{l}\text { Schizo } \\
\text { phrenia }\end{array}$ & $\begin{array}{l}\text { Sodium } \\
\text { deoxycho } \\
\text { late (10) }\end{array}$ & $\begin{array}{l}\text { Phosphatidyl } \\
\text { choline ( } 75)\end{array}$ & $\begin{array}{l}\text { Thin film } \\
\text { hydration } \\
\text { technique } \\
\text { followed } \\
\text { by } \\
\text { sonication, } \\
\text { centrifugat } \\
\text { ion and } \\
\text { freeze- } \\
\text { drying }\end{array}$ & 126 & -43.7 & $\begin{array}{c}\text { Optimised } \\
\text { transferosomes } \\
\text { showed a } \\
\text { permeation 2.3- } \\
\text { fold higher than } \\
\text { liposomal } \\
\text { formulation } \\
\text { without ethanol }\end{array}$ & $\begin{array}{l}\text { Transder } \\
\text { mal } \\
\text { administr } \\
\text { ation of } \\
\text { transferos } \\
\text { omal gel } \\
\text { resulted in } \\
\text { 1.2-fold } \\
\text { lower } \\
\text { than oral } \\
\text { administr } \\
\text { ation of } \\
\text { drug with } \\
\text { carboxym } \\
\text { ethyl } \\
\text { cellulose }\end{array}$ & $\begin{array}{c}\text { Not } \\
\text { reported }\end{array}$ & $\begin{array}{l}\text { (Shrey } \\
\text { a et } \\
\text { al., } \\
2016)\end{array}$ \\
\hline $\begin{array}{l}\text { Clindamy } \\
\text { cin (1) }\end{array}$ & Acne & $\begin{array}{c}\operatorname{Span}^{\circledR} 80 \\
(17.18)\end{array}$ & $\begin{array}{c}\text { Phosphatidyl } \\
\text { choline } \\
(81.82)\end{array}$ & $\begin{array}{l}\text { Thin film } \\
\text { hydration } \\
\text { technique } \\
\text { followed } \\
\text { by } \\
\text { sonication }\end{array}$ & 351 & -40 & $\begin{array}{l}\text { Transferosomal } \\
\text { gel resulted in a } \\
\text { permeation 1.2- } \\
\text { fold higher than } \\
\text { the control gel }\end{array}$ & $\begin{array}{c}\text { Not } \\
\text { reported }\end{array}$ & $\begin{array}{l}\text { No } \\
\text { irritation }\end{array}$ & $\begin{array}{l}\text { (Abde } \\
\text { llatif } \\
\text { and } \\
\text { Tawfe } \\
\text { ek, } \\
2016) \\
\end{array}$ \\
\hline $\begin{array}{c}\text { Paclitaxel } \\
(0.9)\end{array}$ & $\begin{array}{c}\text { Kaposi } \\
\text { sarcom } \\
\text { a }\end{array}$ & $\begin{array}{c}\text { Span } ® 80 \\
(10.62)\end{array}$ & $\begin{array}{l}\text { Phosphatidyl } \\
\text { choline } \\
(67.2)+ \\
\text { cholesterol } \\
(21.28)\end{array}$ & $\begin{array}{l}\text { Thin film } \\
\text { hydration } \\
\text { technique } \\
\text { followed } \\
\text { by } \\
\text { sonication }\end{array}$ & 186 & -23.2 & $\begin{array}{l}\text { Transferosomal } \\
\text { gel resulted in a } \\
\text { permeation } 3.4- \\
\text { fold higher than } \\
\text { the control gel } \\
\text { after } 24 \mathrm{~h}\end{array}$ & $\begin{array}{c}\text { Not } \\
\text { reported }\end{array}$ & $\begin{array}{l}\text { Cytotoxic } \\
\text { ity was } \\
\text { seen in } \\
\text { KSY-1 } \\
\text { cells }\end{array}$ & $\begin{array}{l}\text { (Patha } \\
\text { k et } \\
\text { al., } \\
2016)\end{array}$ \\
\hline $\begin{array}{l}\text { Raloxifen } \\
\text { e (Not } \\
\text { reported) }\end{array}$ & $\begin{array}{l}\text { Osteop } \\
\text { orosis }\end{array}$ & $\begin{array}{l}\text { Sodium } \\
\text { deoxycho } \\
\text { late (Not } \\
\text { reported) }\end{array}$ & $\begin{array}{l}\text { Phosphatidyl } \\
\text { choline (Not } \\
\text { reported) }\end{array}$ & $\begin{array}{l}\text { Thin film } \\
\text { hydration } \\
\text { technique } \\
\text { followed } \\
\text { by } \\
\text { sonication }\end{array}$ & 134 & -9.5 & $\begin{array}{c}\text { Optimised } \\
\text { formulation had } \\
\text { a permeation } \\
\text { profile } 6.5 \text {-fold } \\
\text { better than } \\
\text { nanosize } \\
\text { liposomes } \\
\end{array}$ & $\begin{array}{c}\text { Not } \\
\text { reported }\end{array}$ & $\begin{array}{l}\text { Not } \\
\text { reported }\end{array}$ & $\begin{array}{l}\text { (Mah } \\
\text { mood } \\
\text { et al., } \\
2014)\end{array}$ \\
\hline $\begin{array}{l}\text { Sildenafil } \\
(19.69)\end{array}$ & $\begin{array}{l}\text { Erectile } \\
\text { dysfun } \\
\text { ction }\end{array}$ & $\begin{array}{c}\text { Tween } ® \\
80 \text { and } \\
\text { Span® } 80 \\
(4.02)\end{array}$ & $\begin{array}{c}\text { Phosphatidyl } \\
\text { choline } \\
(76.29)\end{array}$ & $\begin{array}{l}\text { Thin film } \\
\text { hydration } \\
\text { technique } \\
\text { followed }\end{array}$ & 610 & $\begin{array}{c}\text { Not } \\
\text { reporte } \\
\mathrm{d}\end{array}$ & $\begin{array}{l}\text { Optimised } \\
\text { formulation } \\
\text { resulted in } \\
\text { permeation 5- }\end{array}$ & $\begin{array}{l}\text { Not } \\
\text { reported }\end{array}$ & $\begin{array}{l}\text { Not } \\
\text { reported }\end{array}$ & $\begin{array}{l}(\mathrm{Ahm} \\
\text { ed, } \\
2015)\end{array}$ \\
\hline
\end{tabular}




\begin{tabular}{|c|c|c|c|c|c|c|c|c|c|c|}
\hline & & & & $\begin{array}{c}\text { by } \\
\text { sonication }\end{array}$ & & & $\begin{array}{l}\text { fold higher than } \\
\text { drug suspension }\end{array}$ & & & \\
\hline $\begin{array}{l}\text { Felodipin } \\
\text { e (1) }\end{array}$ & $\begin{array}{l}\text { Hypert } \\
\text { ension } \\
\text { and } \\
\text { angina } \\
\text { pectori } \\
\text { s }\end{array}$ & $\begin{array}{c}\text { Tween } ® \\
80 \text { and } \\
\text { Span® } 80 \\
(5)\end{array}$ & $\begin{array}{l}\text { Phosphatidyl } \\
\text { choline (94) }\end{array}$ & $\begin{array}{l}\text { Thin film } \\
\text { hydration } \\
\text { technique } \\
\text { followed } \\
\text { by } \\
\text { sonication }\end{array}$ & 75.71 & -49.8 & $\begin{array}{l}\text { Optimised } \\
\text { formulation } \\
\text { resulted in an } \\
\text { enhancement of } \\
\text { 2.6-fold in drug } \\
\text { permeation } \\
\text { compared to } \\
\text { control gel }\end{array}$ & $\begin{array}{c}\text { Transder } \\
\text { mal } \\
\text { administr } \\
\text { ation of } \\
\text { transferos } \\
\text { omes } \\
\text { showed a } \\
\text { C }_{\text {max }} 3.5- \\
\text { fold } \\
\text { higher } \\
\text { than oral } \\
\text { suspensio } \\
\text { n of } \\
\text { felodipine } \\
\text {. It also } \\
\text { showed a } \\
\text { delay in } \\
\text { the } t_{\text {max }} \\
\text { from } 4.85 \\
\text { to } 6 \text { hours }\end{array}$ & $\begin{array}{l}\text { Not } \\
\text { reported }\end{array}$ & $\begin{array}{l}\text { (Yusu } \\
\text { f et } \\
\text { al., } \\
2014)\end{array}$ \\
\hline $\begin{array}{l}\text { Tretinoin } \\
(0.05)\end{array}$ & Acne & $\begin{array}{l}\text { Tween }{ }^{\circledR} \\
80(20)\end{array}$ & $\begin{array}{l}\text { Phosphatidyl } \\
\text { choline } \\
\text { (79.95) }\end{array}$ & $\begin{array}{l}\text { Sequential } \\
\text { filtration }\end{array}$ & 131 & -5.9 & $\begin{array}{l}15 \% \text { tretinoin } \\
\text { formulation } \\
\text { resulted in } \\
\text { permeation 2- } \\
\text { fold higher than } \\
20 \% \text { tretinoin } \\
\text { formulation }\end{array}$ & $\begin{array}{l}\text { Not } \\
\text { reported }\end{array}$ & $\begin{array}{l}\text { Less } \\
\text { irritating } \\
\text { than } \\
\text { marketed } \\
\text { tretinoin }\end{array}$ & $\begin{array}{l}\text { (Asce } \\
\text { nso et } \\
\text { al., } \\
2014 \text { ) }\end{array}$ \\
\hline $\begin{array}{l}5- \\
\text { Fluoroura } \\
\text { cil }(1)\end{array}$ & $\begin{array}{l}\text { Cutane } \\
\text { ous } \\
\text { melano } \\
\text { ma }\end{array}$ & $\begin{array}{l}\text { Tween }{ }^{\circledR} \\
80(9.9)\end{array}$ & $\begin{array}{l}\text { Phosphatidyl } \\
\text { choline } \\
(89.1)\end{array}$ & $\begin{array}{l}\text { Thin } \\
\text { hydration } \\
\text { technique } \\
\text { followed } \\
\text { by vortex, } \\
\text { sonication } \\
\text { and } \\
\text { extrusion }\end{array}$ & 267 & $\begin{array}{l}\text { Not } \\
\text { reporte } \\
\mathrm{d}\end{array}$ & $\begin{array}{l}\text { Permeation of } \\
\text { this formulation } \\
\text { was } 1.1 \text {-fold } \\
\text { lower using } \\
\text { Tween } ₫ 80 \text { than } \\
\text { using Span } ® 80 \text {, } \\
\text { but entrapment } \\
\text { efficacy and } \\
\text { skin deposition } \\
\text { was lower when } \\
\text { using Span® } 80 \\
\text { as edge activator }\end{array}$ & $\begin{array}{l}\text { Tumour } \\
\text { size } \\
\text { resulted in } \\
\text { 1.9-fold } \\
\text { lower } \\
\text { after } \\
\text { using the } \\
\text { transferos } \\
\text { omal } \\
\text { formulati } \\
\text { on when } \\
\text { compared } \\
\text { to the } \\
\text { marketed } \\
\text { one for } 6 \\
\text { weeks }\end{array}$ & $\begin{array}{c}\text { Not } \\
\text { irritant }\end{array}$ & $\begin{array}{l}\text { (Khan } \\
\text { et al., } \\
\text { 2015) }\end{array}$ \\
\hline $\begin{array}{l}\text { Insulin } \\
\text { (Not } \\
\text { reported) }\end{array}$ & $\begin{array}{l}\text { Diabete } \\
\text { s } \\
\text { mellitu } \\
\text { s }\end{array}$ & $\begin{array}{l}\text { Tween }{ }^{\circledR} \\
80, \\
\text { Span® } 80 \\
\text { or } \\
\text { Sodium } \\
\text { deoxycho } \\
\text { late (Not } \\
\text { reported) }\end{array}$ & $\begin{array}{c}\text { Phosphatidyl } \\
\text { choline + } \\
\text { Cholesterol } \\
\text { (Not } \\
\text { reported) }\end{array}$ & $\begin{array}{c}\text { Reverse } \\
\text { phase } \\
\text { evaporatio } \\
\mathrm{n} \text { followed } \\
\text { by } \\
\text { sonication } \\
\text { and } \\
\text { extrusion }\end{array}$ & 720 & -14.3 & $\begin{array}{c}\text { Permeation of } \\
\text { the optimised } \\
\text { formulation was } \\
\text { 1.3-fold higher } \\
\text { with } \\
\text { iontophoresis } \\
\text { than without it }\end{array}$ & $\begin{array}{l}\text { Glucose } \\
\text { levels } \\
\text { were } \\
1.25 \text {-fold } \\
\text { after } 24 \\
\text { hours } \\
\text { after the } \\
\text { administr } \\
\text { ation of } \\
\text { transferos } \\
\text { omes }\end{array}$ & $\begin{array}{c}\text { Not } \\
\text { reported }\end{array}$ & $\begin{array}{l}\text { (Mala } \\
\text { kar et } \\
\text { al., } \\
2012 \text { ) }\end{array}$ \\
\hline $\begin{array}{l}\text { Insulin- } \\
\text { iodine } \\
(1.2)\end{array}$ & $\begin{array}{l}\text { Diabete } \\
\text { s } \\
\text { mellitu } \\
\text { s }\end{array}$ & $\begin{array}{l}\text { Sodium } \\
\text { deoxycho } \\
\text { late }(25)\end{array}$ & $\begin{array}{l}\text { Phosphatidyl } \\
\text { choline } \\
(73.8)\end{array}$ & $\begin{array}{l}\text { Thin film } \\
\text { hydration } \\
\text { technique } \\
\text { followed } \\
\text { by } \\
\text { sonication }\end{array}$ & 188 & 10.8 & $\begin{array}{c}\text { Transferosomal } \\
\text { gel resulted in a } \\
\text { permeation 1.2- } \\
\text { fold higher than } \\
\text { the } \\
\text { transferosomal } \\
\text { suspension and } \\
\text { 1.3-fold higher } \\
\text { than control gel }\end{array}$ & $\begin{array}{l}\text { Transfero } \\
\text { somal gel } \\
\text { with } \\
\text { iodophor } \\
\text { resulted in } \\
\text { a higher } \\
\text { permeatio } \\
\text { n than the } \\
\text { gel } \\
\text { without } \\
\text { the } \\
\text { iodophor, } \\
\text { but not } \\
\text { significan } \\
\text { tly }\end{array}$ & $\begin{array}{c}\text { Not } \\
\text { reported }\end{array}$ & $\begin{array}{l}\text { (Mar } \\
\text { wah et } \\
\text { al., } \\
\text { 2016) }\end{array}$ \\
\hline $\begin{array}{l}\text { Amphoter } \\
\text { icin B (5) }\end{array}$ & $\begin{array}{c}\text { Viscera } \\
1 \\
\text { leishma } \\
\text { niasis }\end{array}$ & $\begin{array}{l}\text { Sodium } \\
\text { deoxycho } \\
\text { late }(8.6)\end{array}$ & $\begin{array}{c}\text { Phosphatidyl } \\
\text { choline } \\
(60.5)+\end{array}$ & $\begin{array}{l}\text { Thin film } \\
\text { hydration } \\
\text { technique } \\
\text { followed }\end{array}$ & 101 & -50.9 & $\begin{array}{l}\text { Permeation of } \\
\text { the optimised } \\
\text { formulation was } \\
\text { found to be }\end{array}$ & $\begin{array}{c}\text { Not } \\
\text { reported }\end{array}$ & $\begin{array}{c}\text { Not } \\
\text { reported }\end{array}$ & $\begin{array}{l}\text { (Singo } \\
\text { dia et } \\
\text { al., } \\
2010)\end{array}$ \\
\hline
\end{tabular}




\begin{tabular}{|c|c|c|c|c|c|c|c|c|c|c|}
\hline & & & $\begin{array}{c}\text { Cholesterol } \\
(25.9)\end{array}$ & $\begin{array}{c}\text { by } \\
\text { sonication }\end{array}$ & & & $\begin{array}{l}\text { approximately } \\
1.5 \text {-fold higher } \\
\text { compared to } \\
\text { liposomal } \\
\text { formulation }\end{array}$ & & & \\
\hline $\begin{array}{c}\text { Resveratr } \\
\text { ol (Not } \\
\text { reported) }\end{array}$ & $\begin{array}{l}\text { Alzhei } \\
\text { mer }\end{array}$ & $\begin{array}{c}\text { Cremoph } \\
\text { or® RH } \\
40 \text { (Not } \\
\text { reported) }\end{array}$ & $\begin{array}{l}\text { Phosphatidyl } \\
\text { choline (Not } \\
\text { reported) }\end{array}$ & $\begin{array}{l}\text { Thin film } \\
\text { hydration } \\
\text { technique } \\
\text { followed } \\
\text { by } \\
\text { sonication }\end{array}$ & 80 & $\begin{array}{c}\text { Not } \\
\text { reporte } \\
\mathrm{d}\end{array}$ & $\begin{array}{c}\text { Ex vivo } \\
\text { permeation of } \\
\text { the optimised } \\
\text { formulation was } \\
4.5 \text {-fold higher } \\
\text { compared to } \\
\text { suspension. The } \\
\text { kinetics } \\
\text { followed a zero- } \\
\text { order model }\end{array}$ & $\begin{array}{c}\text { Nasal } \\
\text { administr } \\
\text { ation of } \\
\text { transferos } \\
\text { omes } \\
\text { resulted in } \\
\text { a } \mathrm{C}_{\max } 2.1- \\
\text { fold } \\
\text { higher } \\
\text { than the } \\
\text { oral } \\
\text { suspensio } \\
\mathrm{n} \text {, with a } \\
\text { delay in } \\
\text { the } \mathrm{t}_{\text {max }} \\
\text { from } 0.75 \\
\text { to } 7.33 \\
\text { hours }\end{array}$ & $\begin{array}{l}\text { Degenerat } \\
\text { ive } \\
\text { changes } \\
\text { in } \\
\text { olfactory } \\
\text { epitheliu } \\
\text { m and } \\
\text { moderate } \\
\text { infiltratio } \\
\text { n of } \\
\text { mononucl } \\
\text { ear cells } \\
\text { in the } \\
\text { lamina } \\
\text { propria }\end{array}$ & $\begin{array}{c}\text { (Sale } \\
\text { m et } \\
\text { al., } \\
2019)\end{array}$ \\
\hline $\begin{array}{l}\text { Lidocaine } \\
\text { (Not } \\
\text { reported) }\end{array}$ & $\begin{array}{c}\text { Anesth } \\
\text { esic }\end{array}$ & $\begin{array}{c}\text { Sodium } \\
\text { cholate, } \\
\text { Span® } 80 \\
\text { or Brij }{ }^{\circledR} \\
35 \text { (Not } \\
\text { reported) }\end{array}$ & $\begin{array}{c}\text { Phosphatidyl } \\
\text { choline }+ \\
\text { Cholesterol } \\
\text { (Not } \\
\text { reported) }\end{array}$ & $\begin{array}{l}\text { Thin film } \\
\text { hydration } \\
\text { technique } \\
\text { followed } \\
\text { by } \\
\text { sonication }\end{array}$ & 179.5 & -43.5 & $\begin{array}{l}\text { Transferosomal } \\
\text { gels increased } \\
\text { the permeation } \\
\text { of drug when } \\
\text { compared with } \\
\text { lidocaine } \\
\text { solution and gel. } \\
\text { That increase } \\
\text { was dependant } \\
\text { of the } \\
\text { permeation } \\
\text { enhancer that } \\
\text { was used, being } \\
\text { PANAM G3 the } \\
\text { one with a } \\
\text { higher impact } \\
\end{array}$ & $\begin{array}{c}\text { Not } \\
\text { reported }\end{array}$ & $\begin{array}{c}\text { Not } \\
\text { reported }\end{array}$ & $\begin{array}{l}\text { (Omar } \\
\text { et al., } \\
\text { 2019) }\end{array}$ \\
\hline $\begin{array}{l}\text { Raloxifen } \\
\text { e-HCl } \\
\text { (Not } \\
\text { reported) }\end{array}$ & $\begin{array}{l}\text { Breast } \\
\text { cancer }\end{array}$ & $\begin{array}{l}\text { Span® } \\
(\text { Not } \\
\text { reported) }\end{array}$ & $\begin{array}{l}\text { Phosphatidyl } \\
\text { choline (Not } \\
\text { reported) }\end{array}$ & $\begin{array}{l}\text { Thin film } \\
\text { hydration } \\
\text { technique } \\
\text { followed } \\
\text { by } \\
\text { sonication }\end{array}$ & 95.1 & 17.62 & $\begin{array}{c}\text { The } \\
\text { transferosomal } \\
\text { formulation } \\
\text { permeated 4.66- } \\
\text { fold faster than } \\
\text { conventional } \\
\text { liposomes }\end{array}$ & $\begin{array}{c}\text { Not } \\
\text { reported }\end{array}$ & $\begin{array}{c}\text { Not } \\
\text { reported }\end{array}$ & $\begin{array}{l}\text { (Mah } \\
\text { mood } \\
\text { et al., } \\
2018)\end{array}$ \\
\hline
\end{tabular}


Table 2. Preparation of transferosomes using QbD.

\begin{tabular}{|c|c|c|c|c|c|c|c|}
\hline Drug & $\begin{array}{c}\text { Edge } \\
\text { activators }\end{array}$ & Lipids & Factors & Model & Responses & $\begin{array}{l}\text { In vitro } \\
\text { behavior }\end{array}$ & $\begin{array}{c}\text { Referen } \\
\text { ces }\end{array}$ \\
\hline $\begin{array}{c}\text { Zolmitrip } \\
\text { tan }\end{array}$ & $\begin{array}{c}\text { Tween }^{\circledR} \\
80\end{array}$ & $\begin{array}{c}\text { Phosphatidylch } \\
\text { oline }\end{array}$ & $\begin{array}{c}\text { Amount of } \\
\text { phospholipid } \\
\text { Amount of } \\
\text { drug } \\
\text { Amount of } \\
\text { edge activator }\end{array}$ & $\begin{array}{l}\text { Box- } \\
\text { Behnk } \\
\text { en }\end{array}$ & $\begin{array}{c}\text { Particle } \\
\text { size } \\
\text { Flexibility } \\
\text { index } \\
\text { Determinat } \\
\text { ion } \\
\text { coefficient } \\
\text { for } \\
\text { achieving } \\
\text { control } \\
\text { release } \\
\left(\mathrm{R}^{2}\right) \\
\end{array}$ & $\begin{array}{c}1.72 \text {-fold } \\
\text { higher nasal } \\
\text { bioavailabil } \\
\text { ity than } \\
\text { marketed } \\
\text { product }\end{array}$ & $\begin{array}{c}\text { (Pitta et } \\
\text { al., } \\
\text { 2017) }\end{array}$ \\
\hline $\begin{array}{c}\text { Raloxifen } \\
\text { e }\end{array}$ & $\begin{array}{c}\text { Sodium } \\
\text { deoxychol } \\
\text { ate }\end{array}$ & $\begin{array}{c}\text { Phosphatidylch } \\
\text { oline }\end{array}$ & $\begin{array}{c}\text { Amount of } \\
\text { phospholipid } \\
\text { Amount of } \\
\text { edge activator } \\
\text { Sonication time }\end{array}$ & $\begin{array}{c}\text { Box- } \\
\text { Behnk } \\
\text { en }\end{array}$ & $\begin{array}{c}\text { Entrapmen } \\
t \\
\text { efficiency } \\
\text { Particle } \\
\text { size } \\
\text { Transderm } \\
\text { al flux }\end{array}$ & $\begin{array}{c}\text { The } \\
\text { optimised } \\
\text { formulation } \\
\text { resulted in a } \\
6.5 \text {-fold } \\
\text { higher } \\
\text { permeation } \\
\text { than the } \\
\text { nano-size } \\
\text { liposomes }\end{array}$ & $\begin{array}{c}\text { (Mahmo } \\
\text { od et al., } \\
2014)\end{array}$ \\
\hline Valsartan & $\begin{array}{c}\text { Sodium } \\
\text { deoxychol } \\
\text { ate }\end{array}$ & $\begin{array}{c}\text { Phosphatidylch } \\
\text { oline }\end{array}$ & $\begin{array}{c}\text { Amount of } \\
\text { phospholipid } \\
\text { Amount of } \\
\text { drug } \\
\text { Amount of } \\
\text { edge activator } \\
\text { Sonication time }\end{array}$ & $\begin{array}{l}\text { Box- } \\
\text { Behnk } \\
\text { en }\end{array}$ & $\begin{array}{c}\text { Entrapmen } \\
t \\
\text { efficiency } \\
\text { Particle } \\
\text { size } \\
\text { Transderm } \\
\text { al flux }\end{array}$ & $\begin{array}{c}\text { Enhanceme } \\
\text { nt } \\
\text { permeation } \\
\text { ratio of } 33 \\
\text { over drug } \\
\text { entrapped } \\
\text { within } \\
\text { liposomes }\end{array}$ & $\begin{array}{c}\text { (Ahad et } \\
\text { al., } \\
\text { 2012) }\end{array}$ \\
\hline Sildenafil & $\begin{array}{c}\text { Tween }^{\circledR} \\
80 \\
\text { Span }^{\circledR} 80\end{array}$ & $\begin{array}{c}\text { Phosphatidylch } \\
\text { oline }\end{array}$ & $\begin{array}{l}\text { Drug/phospholi } \\
\text { pid ratio } \\
\text { Phospholipid/e } \\
\text { dge activator } \\
\text { ratio } \\
\text { Edge activator } \\
\text { HLB } \\
\text { pH of } \\
\text { hydration } \\
\text { medium } \\
\text { Hydration time } \\
\text { Temperature of } \\
\text { hydration }\end{array}$ & $\begin{array}{c}\text { Placke } \\
\text { tt- } \\
\text { Burma } \\
\text { n }\end{array}$ & $\begin{array}{c}\text { Particle } \\
\text { size } \\
\text { Entrapmen } \\
t \\
\text { efficiency }\end{array}$ & $\begin{array}{c}\text { The } \\
\text { optimised } \\
\text { formulation } \\
\text { showed a } \\
\text { permeation } \\
5 \text {-fold } \\
\text { higher than } \\
\text { drug } \\
\text { suspension }\end{array}$ & $\begin{array}{l}\text { (Ahmed, } \\
\text { 2015) }\end{array}$ \\
\hline Apigenin & $\begin{array}{c}\text { Tween }^{\circledR} \\
80\end{array}$ & $\begin{array}{c}\text { Phosphatidylch } \\
\text { oline }\end{array}$ & $\begin{array}{c}\text { Phospholipid/e } \\
\text { dge activator } \\
\text { ratio } \\
\text { Sonication time } \\
\text { Rotation speed }\end{array}$ & $\begin{array}{l}\text { Box- } \\
\text { Behnk } \\
\text { en }\end{array}$ & $\begin{array}{c}\text { Particle } \\
\text { size } \\
\text { Drug } \\
\text { loading } \\
\text { Entrapmen } \\
t \\
\text { efficiency }\end{array}$ & $\begin{array}{c}\text { Enhanceme } \\
\text { nt } \\
\text { permeation } \\
\text { ratio of } 1.2 \\
\text { over drug } \\
\text { suspension } \\
\text { and } \\
\text { marketed } \\
\text { formulation }\end{array}$ & $\begin{array}{c}\text { (Jangdey } \\
\text { et al., } \\
\text { 2017) }\end{array}$ \\
\hline Timolol & $\operatorname{Span}^{\circledR} 80$ & $\begin{array}{c}\text { Phosphatidylch } \\
\text { oline }\end{array}$ & $\begin{array}{c}\text { Phospholipid/e } \\
\text { dge activator } \\
\text { ratio } \\
\text { Carrier/mixture } \\
\text { ratio } \\
\text { Carrier type }\end{array}$ & $\begin{array}{c}2^{3} \text { full } \\
\text { factori } \\
\text { al } \\
\text { design }\end{array}$ & $\begin{array}{l}\text { Particle } \\
\text { size } \\
\text { Entrapmen } \\
t \\
\text { efficiency } \\
\text { Release } \\
\text { rate } \\
\end{array}$ & $\begin{array}{l}\text { Permeation } \\
\text { ratio was } \\
1.3-\text { fold } \\
\text { higher in } \\
\text { the } \\
\text { formulation } \\
\text { with spray- }\end{array}$ & $\begin{array}{l}\text { (Morsi } \\
\text { et al., } \\
2017 \text { ) }\end{array}$ \\
\hline
\end{tabular}




\begin{tabular}{|c|c|c|c|c|c|c|c|}
\hline & & & & & & $\begin{array}{c}\text { dried } \\
\text { lactose } \\
\text { Release rate } \\
\text { was } 1.1 \\
\text { fold higher } \\
\text { in the } \\
\text { formulation } \\
\text { containing } \\
\text { mannitol }\end{array}$ & \\
\hline Paclitaxel & $\operatorname{Span}^{\circledR} 80$ & $\begin{array}{c}\text { Phosphatidylch } \\
\text { oline } \\
\text { Cholesterol }\end{array}$ & $\begin{array}{c}\text { Concentration } \\
\text { of soya lecithin } \\
\text { Concentration } \\
\text { of cholesterol } \\
\text { Concentration } \\
\text { of Span }{ }^{\circledR} 80\end{array}$ & $\begin{array}{l}\text { Box- } \\
\text { Behnk } \\
\text { en }\end{array}$ & $\begin{array}{c}\text { Entrapmen } \\
t \\
\text { efficiency } \\
\text { Particle } \\
\text { size } \\
\text { Cumulativ } \\
\text { e drug } \\
\text { permeation }\end{array}$ & $\begin{array}{c}\text { Transferoso } \\
\text { mal gel } \\
\text { resulted in a } \\
\text { permeation } \\
\text { 3.4-fold } \\
\text { higher than } \\
\text { the control } \\
\text { gel after } 24 \\
\text { h } \\
\end{array}$ & $\begin{array}{l}\text { (Pathak } \\
\text { et al., } \\
\text { 2016) }\end{array}$ \\
\hline $\begin{array}{c}\text { Miconazo } \\
\text { le }\end{array}$ & $\begin{array}{c}\text { Span }^{\circledR} 80 \\
\text { Tween }^{\circledR} \\
80\end{array}$ & $\begin{array}{c}\text { Phosphatidylch } \\
\text { oline }\end{array}$ & $\begin{array}{c}\text { Type of } \\
\text { surfactant } \\
\text { Amount of } \\
\text { lipids } \\
\text { Phospholipid/e } \\
\text { dge activator } \\
\text { ratio }\end{array}$ & $\begin{array}{l}2^{3} \text { full } \\
\text { factori } \\
\text { al } \\
\text { design }\end{array}$ & $\begin{array}{c}\text { Entrapmen } \\
\mathrm{t} \\
\text { efficiency } \\
\text { Particle } \\
\text { size } \\
\text { Transderm } \\
\text { al flux }\end{array}$ & $\begin{array}{c}\text { Transferoso } \\
\text { mal gel } \\
\text { resulted in a } \\
\text { permeation } \\
1.19 \text {-fold } \\
\text { higher than } \\
\text { Daktarin }{ }^{\circledR} \\
\text { after } 24 \mathrm{~h}\end{array}$ & $\begin{array}{c}\text { (Qushaw } \\
\text { y et al., } \\
2018)\end{array}$ \\
\hline Insulin & $\begin{array}{c}\text { Tween }^{\circledR} \\
80 \\
\text { Sodium } \\
\text { deoxychol } \\
\text { ate }\end{array}$ & $\begin{array}{c}\text { Phosphatidylch } \\
\text { oline } \\
\text { Cholesterol }\end{array}$ & $\begin{array}{c}\text { Phosphatidyl } \\
\text { choline/cholest } \\
\text { erol ratio } \\
\text { Lipids/edge } \\
\text { activator ratio } \\
\text { Tween }{ }^{\circledR} \\
\text { 80/sodium } \\
\text { deoxycholate } \\
\text { ratio }\end{array}$ & $\begin{array}{l}2^{3} \text { full } \\
\text { factori } \\
\text { al } \\
\text { design }\end{array}$ & Flux & $\begin{array}{c}\text { Optimised } \\
\text { formulation } \\
\text { had a } \\
\text { permeation } \\
1.3 \text {-fold } \\
\text { higher with } \\
\text { iontophores } \\
\text { is than } \\
\text { without it }\end{array}$ & $\begin{array}{c}\text { (Malaka } \\
\text { r et al., } \\
2012)\end{array}$ \\
\hline $\begin{array}{c}\text { Resveratr } \\
\text { ol }\end{array}$ & $\begin{array}{c}\text { Tween }^{\circledR} \\
80 \\
\text { Sodium } \\
\text { deoxychol } \\
\text { ate } \\
\text { Cromoph } \\
\text { or }^{\circledR} \text { RH40 }\end{array}$ & $\begin{array}{c}\text { Phosphatidylch } \\
\text { oline }\end{array}$ & $\begin{array}{c}\text { Phosphatidyl } \\
\text { choline/permea } \\
\text { tion enhancer } \\
\text { ratio } \\
\text { (Phosphatidyl } \\
\text { choline+Perme } \\
\text { ation } \\
\text { enhancer)/edge } \\
\text { activator ratio } \\
\text { Type of edge } \\
\text { activator } \\
\text { Type of } \\
\text { permeation } \\
\text { enhancer }\end{array}$ & $\begin{array}{c}3^{4} \\
\text { design }\end{array}$ & $\begin{array}{c}\text { Particle } \\
\text { size } \\
\text { Polydisper } \\
\text { sity index } \\
\text { Zeta- } \\
\text { potential } \\
\text { Entrapmen } \\
\text { t } \\
\text { efficiency }\end{array}$ & $\begin{array}{l}\text { Ex vivo } \\
\text { permeation } \\
\text { of the } \\
\text { optimised } \\
\text { formulation } \\
\text { was 4.5- } \\
\text { fold higher } \\
\text { compared } \\
\text { to } \\
\text { suspension. } \\
\text { The } \\
\text { kinetics } \\
\text { followed a } \\
\text { zero-order } \\
\text { model }\end{array}$ & $\begin{array}{l}\text { (Salem } \\
\text { et al., } \\
\text { 2019) }\end{array}$ \\
\hline
\end{tabular}


Table 3. Comparison among the different techniques employed in the preparation of transferosomes.

\begin{tabular}{|c|c|c|c|c|}
\hline Technique & Advantages & Disadvantages & $\begin{array}{c}\text { Laboratory } \\
\text { or industrial } \\
\text { scale }\end{array}$ & References \\
\hline $\begin{array}{l}\text { Thin film } \\
\text { hydration }\end{array}$ & $\begin{array}{l}\text { Suitable for all kind of lipids } \\
\text { Easy to perform } \\
\text { High drug encapsulation rates }\end{array}$ & $\begin{array}{l}\text { Difficult to scale-up } \\
\text { Long time } \\
\text { High cost }\end{array}$ & Lab scale & $\begin{array}{l}\text { (Ahmed, 2015; } \\
\text { Mahmood et } \\
\text { al., 2014; Pitta } \\
\text { et al., 2017; } \\
\text { Wagner and } \\
\text { Vorauer-Uhl, } \\
\text { 2011) }\end{array}$ \\
\hline Sonication & $\begin{array}{l}\text { High effiency in reducing particle } \\
\text { size }\end{array}$ & $\begin{array}{l}\text { It is not a technique by } \\
\text { itself, but it is commonly } \\
\text { used after thin film } \\
\text { hydration. } \\
\text { Difficult to scale-up }\end{array}$ & Lab scale & $\begin{array}{l}\text { (Wagner and } \\
\text { Vorauer-Uhl, } \\
\text { 2011) }\end{array}$ \\
\hline $\begin{array}{l}\text { Homogenization/ } \\
\text { Extrusion }\end{array}$ & $\begin{array}{l}\text { Less aggressive than sonication } \\
\text { Easy to scale-up } \\
\text { High reproducibility of } \\
\text { downsizing }\end{array}$ & $\begin{array}{c}\text { Long-lasting preparation } \\
\text { High product losses } \\
\text { High cost }\end{array}$ & Both & $\begin{array}{l}\text { (Wagner and } \\
\text { Vorauer-Uhl, } \\
\text { 2011) }\end{array}$ \\
\hline $\begin{array}{l}\text { Ethanol injection } \\
\text { method }\end{array}$ & $\begin{array}{c}\text { Easy to scale-up } \\
\text { Ethanol is a harmless solvent } \\
\text { Higher stability } \\
\text { High entrapment efficacy }\end{array}$ & $\begin{array}{l}\text { The obtained } \\
\text { formulation might be an } \\
\text { ethosome instead of a } \\
\text { transferosome }\end{array}$ & Industrial & $\begin{array}{l}\text { (Wagner and } \\
\text { Vorauer-Uhl, } \\
\text { 2011) }\end{array}$ \\
\hline $\begin{array}{l}\text { Protransferosome } \\
\text {-transferosome } \\
\text { method }\end{array}$ & $\begin{array}{l}\text { High entrapment efficacy } \\
\text { Easy to scale-up }\end{array}$ & $\begin{array}{l}\text { High amount of product } \\
\text { is needed to be diluted in } \\
\text { a second step }\end{array}$ & Industrial & $\begin{array}{l}\text { (Davidson et } \\
\text { al., 2016; } \\
\text { Wagner and } \\
\text { Vorauer-Uhl, } \\
\text { 2011) }\end{array}$ \\
\hline Microfluidics & $\begin{array}{l}\text { Possibility of monitoring the } \\
\text { process }\end{array}$ & $\begin{array}{l}\text { Requires the use of } \\
\text { HPLC grade compounds, } \\
\text { which increases the cost }\end{array}$ & Industrial & $\begin{array}{l}\text { (Carugo et al., } \\
\text { 2016; Golden } \\
\text { et al., 2012; } \\
\text { Sugiura et al., } \\
\text { 2008) }\end{array}$ \\
\hline
\end{tabular}




\section{References}

Design Expert software. Stat-Ease, https://shop.statease.com/software/design-expert/. Abdellatif, A.A., Tawfeek, H.M., 2016. Transfersomal Nanoparticles for Enhanced Transdermal Delivery of Clindamycin. AAPS PharmSciTech 17, 1067-1074.

Adam, S., Suzzi, D., Radeke, C., Khinast, J.G., 2011. An integrated Quality by Design (QbD) approach towards design space definition of a blending unit operation by Discrete Element Method (DEM) simulation. Eur J Pharm Sci 42, 106-115.

AEMPS, 2017. Ambisome 50 mg, powder for infusion, data sheet. Agencia Española de Medicamentos y Productos Sanitarios.

Agarwal, R., Katare, O.P., Vyas, S.P., 2001. Preparation and in vitro evaluation of liposomal/niosomal delivery systems for antipsoriatic drug dithranol. Int J Pharm 228, 43-52.

Ahad, A., Al-Saleh, A.A., Al-Mohizea, A.M., Al-Jenoobi, F.I., Raish, M., Yassin, A.E.B., Alam, M.A., 2017. Formulation and characterization of novel soft nanovesicles for enhanced transdermal delivery of eprosartan mesylate. Saudi Pharm J 25, 1040-1046.

Ahad, A., Aqil, M., Kohli, K., Sultana, Y., Mujeeb, M., Ali, A., 2012a. Formulation and optimization of nanotransfersomes using experimental design technique for accentuated transdermal delivery of valsartan. Nanomedicine 8, 237-249.

Ahad, A., Aqil, M., Kohli, K., Sultana, Y., Mujeeb, M., Ali, A., 2012b. Formulation and optimization of nanotransfersomes using experimental design technique for accentuated transdermal delivery of valsartan. Nanomed-Nanotechnol 8, 237-249.

Ahmed, T.A., 2015. Preparation of transfersomes encapsulating sildenafil aimed for transdermal drug delivery: Plackett-Burman design and characterization. J Liposome Res 25, 1-10.

Al Shuwaili, A.H., Rasool, B.K., Abdulrasool, A.A., 2016. Optimization of elastic transfersomes formulations for transdermal delivery of pentoxifylline. Eur J Pharm Biopharm 102, 101-114.

Ali, M.F., Salem, H.F., Abdelmohsen, H.F., Attia, S.K., 2015. Preparation and clinical evaluation of nano-transferosomes for treatment of erectile dysfunction. Drug Des Devel Ther 9, 2431-2447.

Ascenso, A., Salgado, A., Euleterio, C., Praca, F.G., Bentley, M.V., Marques, H.C., Oliveira, H., Santos, C., Simoes, S., 2014. In vitro and in vivo topical delivery studies of tretinoinloaded ultradeformable vesicles. Eur J Pharm Biopharm 88, 48-55.

Azimi, M., Khodabandeh, M., Deezagi, A., Rahimi, F., 2019. Impact of the transfersome delivered human growth hormone on the dermal fibroblast cells. Curr Pharm Biotechnol.

Benson, H.A., 2006. Transfersomes for transdermal drug delivery. Expert Opin Drug Deliv 3, 727-737.

Bezerra, M.A., Santelli, R.E., Oliveira, E.P., Villar, L.S., Escaleira, L.A., 2008. Response surface methodology (RSM) as a tool for optimization in analytical chemistry. Talanta 76, 965-977.

Carugo, D., Bottaro, E., Owen, J., Stride, E., Nastruzzi, C., 2016. Liposome production by microfluidics: potential and limiting factors. Sci Rep 6, 25876.

Chen, H.J., Chang, S.N., Tang, C.W., 2017. Application of the Taguchi Method for Optimizing the Process Parameters of Producing Lightweight Aggregates by Incorporating Tile Grinding Sludge with Reservoir Sediments. Materials (Basel) 10. 
Colombo, A.P., Briancon, S., Lieto, J., Fessi, H., 2001. Project, design, and use of a pilot plant for nanocapsule production. Drug Development and Industrial Pharmacy 27, 10631072.

Csanyi, E., Bakonyi, M., Kovacs, A., Budai-Szucs, M., Berko, S., 2018. Development of Topical Nanocarriers for Skin Cancer Treatment Using Quality by Design Approach. Curr Med Chem.

Davidson, E.M., Haroutounian, S., Kagan, L., Naveh, M., Aharon, A., Ginosar, Y., 2016. A Novel Proliposomal Ropivacaine Oil: Pharmacokinetic-Pharmacodynamic Studies After Subcutaneous Administration in Pigs. Anesth Analg 122, 1663-1672.

Defeo, J.A., 2016. Juran's Quality Handbook: The Complete Guide to Performance Excellence, Seventh Edition. McGraw-Hill Education.

DrugBank, 2019. Drug Bank: ketoprofen physicochemical properties. Drug Bank.

El Maghraby, G.M., Williams, A.C., Barry, B.W., 2004. Interactions of surfactants (edge activators) and skin penetration enhancers with liposomes. Int J Pharm 276, 143-161.

Fathi-Azarbayjani, A., Ng, K.X., Chan, Y.W., Chan, S.Y., 2015. Lipid Vesicles for the Skin Delivery of Diclofenac: Cerosomes vs. Other Lipid Suspensions. Adv Pharm Bull 5, 25-33. Ferreira, S.L., Bruns, R.E., Ferreira, H.S., Matos, G.D., David, J.M., Brandao, G.C., da Silva, E.G., Portugal, L.A., dos Reis, P.S., Souza, A.S., dos Santos, W.N., 2007. Box-Behnken design: an alternative for the optimization of analytical methods. Anal Chim Acta 597, 179-186.

Gilani, S.J., Rizwanullah, M., Imam, S.S., Pandit, J., Aqil, M., Alam, M., Beg, S., 2019. QbD Considerations for Topical and Transdermal Product Development, Pharmaceutical Quality by Design. Academic Press, pp. 131-150.

Girard, P., Pecreaux, J., Lenoir, G., Falson, P., Rigaud, J.L., Bassereau, P., 2004. A new method for the reconstitution of membrane proteins into giant unilamellar vesicles. Biophys J 87, 419-429.

Golden, J.P., Justin, G.A., Nasir, M., Ligler, F.S., 2012. Hydrodynamic focusing--a versatile tool. Anal Bioanal Chem 402, 325-335.

Hadgraft, J., Lane, M.E., 2011. Skin: the ultimate interface. Physical chemistry chemical physics : PCCP 13, 5215-5222.

Hadidi, N., Saffari, M., Faizi, M., 2018. Optimized Transferosomal Bovine Lactoferrin (BLF) as a Promising Novel Non-Invasive Topical Treatment for Genital Warts Caused by Human Papiluma Virus (HPV). Iran J Pharm Res 17, 12-23.

Hanaor, D., Michelazzi, M., Leonelli, C., Sorrell, C.C., 2012. The effects of carboxylic acids on the aqueous dispersion and electrophoretic deposition of ZrO2. J Eur Ceram Soc 32, 235-244.

Ishikawa, S., Tateya, I., Hayasaka, T., Shinriki, S., Masaki, N., Hirano, S., Kitamura, M., Muto, M., Morita, S., Setou, M., Ito, J., 2017. The Distribution of Phosphatidylcholine Species in Superficial-Type Pharyngeal Carcinoma. Biomed Res Int 2017, 5387913.

Ita, K., 2016. Perspectives on Transdermal Electroporation. Pharmaceutics 8.

Jangdey, M.S., Gupta, A., Saraf, S., Saraf, S., 2017. Development and optimization of apigenin-loaded transfersomal system for skin cancer delivery: in vitro evaluation. Artif Cells Nanomed Biotechnol 45, 1452-1462.

Jeon, S., Yoo, C.Y., Park, S.N., 2015. Improved stability and skin permeability of sodium hyaluronate-chitosan multilayered liposomes by Layer-by-Layer electrostatic deposition for quercetin delivery. Colloid Surface B 129, 7-14. 
Jiang, T.Y., Wang, T., Li, T., Ma, Y.D., Shen, S.Y., He, B.F., Mo, R., 2018. Enhanced Transdermal Drug Delivery by Transfersome-Embedded Oligopeptide Hydrogel for Topical Chemotherapy of Melanoma. Acs Nano 12, 9693-9701.

Junghanns, J.U.A.H., Muller, R.H., 2008. Nanocrystal technology, drug delivery and clinical applications. Int J Nanomed 3, 295-309.

Karpinski, T.M., 2018. Selected Medicines Used in lontophoresis. Pharmaceutics 10. Khajeh, M., 2009. Application of Box-Behnken design in the optimization of a magnetic nanoparticle procedure for zinc determination in analytical samples by inductively coupled plasma optical emission spectrometry. J Hazard Mater 172, 385-389.

Khan, M.A., Pandit, J., Sultana, Y., Sultana, S., Ali, A., Aqil, M., Chauhan, M., 2015. Novel carbopol-based transfersomal gel of 5-fluorouracil for skin cancer treatment: in vitro characterization and in vivo study. Drug Deliv 22, 795-802.

Kleesz, P., Darlenski, R., Fluhr, J.W., 2012. Full-body skin mapping for six biophysical parameters: baseline values at 16 anatomical sites in 125 human subjects. Skin pharmacology and physiology 25, 25-33.

Kneer, W., Rother, I., Rother, M., Seidel, E., Group, I.-I.-S., 2009. A multiple-dose, openlabel, safety, compliance, and usage evaluation study of epicutaneously applied Diractin (ketoprofen in Transfersome) in joint/musculoskeletal pain or soft tissue inflammation. Curr Drug Saf 4, 5-10.

Kneer, W., Rother, M., Mazgareanu, S., Seidel, E.J., European, I.-s.g., 2013. A 12-week randomized study of topical therapy with three dosages of ketoprofen in Transfersome(R) gel (IDEA-033) compared with the ketoprofen-free vehicle (TDT 064), in patients with osteoarthritis of the knee. Journal of pain research 6, 743-753.

Kraft, J.C., Freeling, J.P., Wang, Z.Y., Ho, R.J.Y., 2014. Emerging Research and Clinical Development Trends of Liposome and Lipid Nanoparticle Drug Delivery Systems. J Pharm Sci-Us 103, 29-52.

Lasch, J., Laub, R., Wohlrab, W., 1992. How deep do intact liposomes penetrate into human skin? . J Control Release 18, 55-58.

Lymberopoulos, A., Demopoulo, C., Kyriazi, M., 2017. Liposome percutaneous penetration in vivo. Toxicology Research and Application 1.

Mahmood, S., Chatterjee, B., Mandal, U.K., 2018. Nano Transfersomes Vesicles of Raloxifene $\mathrm{HCl}$ with Sorbitan 80: Formulation and Characterization. Bioequiv \& Bioavailab Int J 2(1): 000121.

Mahmood, S., Taher, M., Mandal, U.K., 2014. Experimental design and optimization of raloxifene hydrochloride loaded nanotransfersomes for transdermal application. Int J Nanomedicine 9, 4331-4346.

Malakar, J., Sen, S.O., Nayak, A.K., Sen, K.K., 2012. Formulation, optimization and evaluation of transferosomal gel for transdermal insulin delivery. Saudi Pharm J 20, 355363.

Marwah, H., Garg, T., Rath, G., Goyal, A.K., 2016. Development of transferosomal gel for trans-dermal delivery of insulin using iodine complex. Drug Deliv 23, 1636-1644.

Morrow, D.I., Garland, M.J., McCarron, P.A., Woolfson, A.D., Donnelly, R.F., 2007. Innovative drug delivery strategies for topical photodynamic therapy using porphyrin precursors. J Environ Pathol Toxicol Oncol 26, 105-116.

Morsi, N.M., Aboelwafa, A.A., Dawoud, M.H.S., 2017. Enhancement of the bioavailability of an antihypertensive drug by transdermal protransfersomal system: formulation and in vivo study. J Liposome Res, 1-12. 
Naik, U.S., 2013. title., University of Central Lancashire, Preston, UK.

Omar, M.M., Hasan, O.A., El Sisi, A.M., 2019. Preparation and optimization of lidocaine transferosomal gel containing permeation enhancers: a promising approach for enhancement of skin permeation. Int J Nanomed 14, 1551-1562.

Paliwal, R., Babu, R.J., Palakurthi, S., 2014. Nanomedicine Scale-up Technologies: Feasibilities and Challenges. Aaps Pharmscitech 15, 1527-1534.

Panwar, P., Pandey, B., Lakhera, P.C., Singh, K.P., 2010. Preparation, characterization, and in vitro release study of albendazole-encapsulated nanosize liposomes. Int J Nanomed 5, 101-108.

Parker, A.E., Walker, D.K., Goeres, D.M., Allan, N., Olson, M.E., Omar, A., 2014. Ruggedness and reproducibility of the MBEC biofilm disinfectant efficacy test. J Microbiol Methods 102, 55-64.

Pathak, K., Sharma, V., Sharma, M., 2016. Optimization, in vitro cytotoxicity and penetration capability of deformable nanovesicles of paclitaxel for dermal chemotherapy in Kaposi sarcoma. Artif Cells Nanomed Biotechnol 44, 1671-1683.

Peralta, M.F., Guzman, M.L., Perez, A.P., Apezteguia, G.A., Formica, M.L., Romero, E.L., Olivera, M.E., Carrer, D.C., 2018. Liposomes can both enhance or reduce drugs penetration through the skin. Sci Rep-Uk 8.

Pitta, S.K., Dudhipala, N., Narala, A., Veerabrahma, K., 2017. Development of zolmitriptan transfersomes by Box-Behnken design for nasal delivery: in vitro and in vivo evaluation. Drug Dev Ind Pharm, 1-24.

Prausnitz, M.R., Elias, P.M., Franz, T.J., Schmuth, M., Tsai, J., Menon, G.K., Holleran, W.M., Feingold, K.R., 2012. Skin Barrier and Transdermal Drug Delivery, in: Bolognia, J.L., Jorizzo, J.L., Schaffer, J.V. (Eds.), Dermatology. Elsevier Health Sciences, pp. 2065-2073. Prausnitz, M.R., Langer, R., 2008. Transdermal drug delivery. Nat Biotechnol 26, 12611268.

Qushawy, M., Nasr, A., Abd-Alhaseeb, M., Swidan, S., 2018. Design, Optimization and Characterization of a Transfersomal Gel Using Miconazole Nitrate for the Treatment of Candida Skin Infections. Pharmaceutics 10.

Rai, S., Pandey, V., Rai, G., 2017. Transfersomes as versatile and flexible nanovesicular carriers in skin cancer therapy: the state of the art. Nano Reviews \& Experiments 8, 115.

Raj, R., Raj, P.M., Ram, A., 2016. Lipid based noninvasive vesicular formulation of cytarabine: Nanodeformable liposomes. Eur J Pharm Sci 88, 83-90.

Rajan, R., Jose, S., Mukund, V.P., Vasudevan, D.T., 2011. Transferosomes - A vesicular transdermal delivery system for enhanced drug permeation. Journal of advanced pharmaceutical technology \& research 2, 138-143.

Rane, B.R., Gujarathi, N.A., 2016. Transfersomes and Protransfersome: Ultradeformable Vesicular System, in: Keservani, R.K., Sharma, A.K., Kesharwani, R.K. (Eds.), Novel Approaches for Drug Delivery. IGI Global, pp. 149-169.

Rao, R.S., Kumar, C.G., Prakasham, R.S., Hobbs, P.J., 2008. The Taguchi methodology as a statistical tool for biotechnological applications: a critical appraisal. Biotechnol J 3, 510-523.

Rathore, A.S., Winkle, H., 2009. Quality by design for biopharmaceuticals. Nat Biotechnol 27, 26-34. 
Reddy, Y.K., Sravani, A.B., Ravisankar, V., Prakash, P.R., Reddy, Y.S.R., Bhaskar, N.V., 2015. Transferosomes A Novel Vesicular Carrier for Transdermal Drug Delivery System. J Innov Pharm Vol 2 (2), 193-208, 2015.

Rispoli, F., Shah, V., 2008. Optimization of the media ingredients for cutinase production from Colleotrichum lindemuthianum using mixture design experiments. Biotechnol Prog 24, 648-654.

Rother, M., Seidel, E.J., Clarkson, P.M., Mazgareanu, S., Vierl, U., Rother, I., 2009. Efficacy of epicutaneous Diractin (ketoprofen in Transfersome gel) for the treatment of pain related to eccentric muscle contractions. Drug Des Devel Ther 3, 143-149.

Salem, H.F., Kharshoum, R.M., Abou-Taleb, H.A., Naguib, D.M., 2019. Nanosized Transferosome-Based Intranasal In Situ Gel for Brain Targeting of Resveratrol: Formulation, Optimization, In Vitro Evaluation, and In Vivo Pharmacokinetic Study. Aaps Pharmscitech 20.

Savic, I.M., Marinkovic, V.D., Tasic, L., Krajnovic, D., Savic, I.M., 2012. From experimental design to quality by design in pharmaceutical legislation. Accredit Qual Assur 17, 627633.

Sessa, G., Weissmann, G., 1970. Incorporation of Lysozyme into Liposomes - a Model for Structure-Linked Latency. J Biol Chem 245, 3295-+.

Shreya, A.B., Managuli, R.S., Menon, J., Kondapalli, L., Hegde, A.R., Avadhani, K., Shetty, P.K., Amirthalingam, M., Kalthur, G., Mutalik, S., 2016. Nano-transfersomal formulations for transdermal delivery of asenapine maleate: in vitro and in vivo performance evaluations. J Liposome Res 26, 221-232.

Singodia, D., Gupta, G.K., Verma, A., Singh, V., Shukla, P., Misra, P., Sundar, S., Dube, A., Mishra, P.R., 2010. Development and performance evaluation of amphotericin B transfersomes against resistant and sensitive clinical isolates of visceral leishmaniasis. J Biomed Nanotechnol 6, 293-302.

Stachowiak, J.C., Richmond, D.L., Li, T.H., Liu, A.P., Parekh, S.H., Fletcher, D.A., 2008. Unilamellar vesicle formation and encapsulation by microfluidic jetting. Proc Natl Acad Sci U S A 105, 4697-4702.

Sugiura, S., Kuroiwa, T., Kagota, T., Nakajima, M., Sato, S., Mukataka, S., Walde, P., Ichikawa, S., 2008. Novel method for obtaining homogeneous giant vesicles from a monodisperse water-in-oil emulsion prepared with a microfluidic device. Langmuir 24, 4581-4588.

Thakkar, H.P., Savsani, H., Kumar, P., 2016. Ethosomal Hydrogel of Raloxifene HCl: Statistical Optimization \& Ex Vivo Permeability Evaluation Across Microporated Pig Ear Skin. Curr Drug Deliv 13, 1111-1122.

van Hoogevest, P., Wendel, A., 2014. The use of natural and synthetic phospholipids as pharmaceutical excipients. Eur J Lipid Sci Technol 116, 1088-1107.

van Zyl, L., Viljoen, J.M., Haynes, R.K., Aucamp, M., Ngwane, A.H., du Plessis, J., 2019. Topical Delivery of Artemisone, Clofazimine and Decoquinate Encapsulated in Vesicles and Their In vitro Efficacy Against Mycobacterium tuberculosis. Aaps Pharmscitech 20. Verma, D.D., Verma, S., Blume, G., Fahr, A., 2003. Particle size of liposomes influences dermal delivery of substances into skin. Int J Pharmaceut 258, 141-151.

Wagner, A., Vorauer-Uhl, K., 2011. Liposome technology for industrial purposes. J Drug Deliv 2011, 591325.

Wang, J., Wei, Y., Fei, Y.R., Fang, L., Zheng, H.S., Mu, C.F., Li, F.Z., Zhang, Y.S., 2017. Preparation of mixed monoterpenes edge activated PEGylated transfersomes to 
improve the in vivo transdermal delivery efficiency of sinomenine hydrochloride. Int J Pharm 533, 266-274.

Wu, X.J., Li, Y., Chen, X.G., Zhou, Z.Z., Pang, J.H., Luo, X., Kong, M., 2019. A surface charge dependent enhanced Th1 antigen-specific immune response in lymph nodes by transfersome-based nanovaccine-loaded dissolving microneedle-assisted transdermal immunization. J Mater Chem B 7, 4854-4866.

Yang, J., Liu, X.L., Fu, Y.Z., Song, Y.J., 2019. Recent advances of microneedles for biomedical applications: drug delivery and beyond. Acta Pharm Sin B 9, 469-483.

Yang, X., Patel, S., Sheng, Y., Pal, D., Mitra, A.K., 2014. Statistical design for formulation optimization of hydrocortisone butyrate-loaded PLGA nanoparticles. AAPS PharmSciTech 15, 569-587.

Yusuf, M., Sharma, V., Pathak, K., 2014. Nanovesicles for transdermal delivery of felodipine: Development, characterization, and pharmacokinetics. Int J Pharm Investig 4, 119-130.

Zhang, L.Z., Wang, J.G., Chi, H.M., Wang, S.L., 2016. Local anesthetic lidocaine delivery system: chitosan and hyaluronic acid-modified layer-by-layer lipid nanoparticles. Drug Delivery 23, 3529-3537.

Zhao, A., Chen, F., Ning, C., Wu, H., Song, H., Wu, Y., Chen, R., Zhou, K., Xu, X., Lu, Y., Gao, J., 2017. Use of real-time cellular analysis and Plackett-Burman design to develop the serum-free media for PC-3 prostate cancer cells. PLoS One 12, e0185470. 